\title{
BLACK-TAILED AND WHITE-TAILED JACKRABBITS IN THE AMERICAN WEST: HISTORY, ECOLOGY, ECOLOGICAL SIGNIFICANCE, AND SURVEY METHODS
}

\author{
Matthew T. Simes ${ }^{1,5}$, Kathleen M. Longshore ${ }^{1}$, Kenneth E. Nussear ${ }^{1,2}$, \\ Greg L. Beatty ${ }^{3}$, David E. Brown ${ }^{4}$, and Todd C. Esque ${ }^{1}$
}

ABstract.-Across the western United States, Leporidae are the most important prey item in the diet of Golden Eagles (Aquila chrysaetos). Leporids inhabiting the western United States include black-tailed (Lepus californicus) and white-tailed jackrabbits (Lepus townsendii) and various species of cottontail rabbit (Sylvilagus spp.). Jackrabbits (Lepus spp.) are particularly important components of the ecological and economic landscape of western North America because their abundance influences the reproductive success and population trends of predators such as coyotes (Canis latrans), bobcats (Lynx rufus), and a number of raptor species. Here, we review literature pertaining to black-tailed and white-tailed jackrabbits comprising over 170 published journal articles, notes, technical reports, conference proceedings, academic theses and dissertations, and other sources dating from the late 19th century to the present. Our goal is to present information to assist those in research and management, particularly with regard to protected raptor species (e.g., Golden Eagles), mammalian predators, and ecological monitoring. We classified literature sources as (1) general information on jackrabbit species, (2) black-tailed or (3) white-tailed jackrabbit ecology and natural history, or (4) survey methods. These categories, especially 2, 3, and 4, were further subdivided as appropriate. The review also produced several tables on population trends, food habits, densities within various habitats, and jackrabbit growth and development. Black-tailed and white-tailed jackrabbits are ecologically similar in general behaviors, use of forms, parasites, and food habits, and they are prey to similar predators; but they differ in their preferred habitats. While the black-tailed jackrabbit inhabits agricultural land, deserts, and shrublands, the white-tailed jackrabbit is associated with prairies, alpine tundra, and sagebrush-steppe. Frequently considered abundant, jackrabbit numbers in western North America fluctuate temporally and spatially. We also reviewed methods used to investigate jackrabbit populations, including spotlight line transects, flushing transects, drive counts, pellet plot counts, collections, roadside counts, mark-recapture studies, and radio-telemetry studies. Our review of jackrabbit literature illustrates a number of deficiencies in our understanding of jackrabbits in general. As an example, a detailed quantitative description of habitat preferences is lacking, as is a thorough understanding of sympatric jackrabbit species interactions. Even the existence of the oft-cited jackrabbit "cycle" is a matter of debate. Survey methods generally do not address efficacy or accuracy in measuring jackrabbit density or abundance. In addition, there is a paucity of information about jackrabbits in the Mojave Desert, with no real understanding of home ranges, habitat preferences, and population dynamics or demographics in this region.

REsumen.-A lo largo del oeste de Estados Unidos los lagomorfos son una de las presas más importantes en la dieta del águila real (Aquila chrysaetos). Entre los lagomorfos que habitan el oeste de los EE.UU. se encuentran las liebres de cola negra (Lepus californicus) y las liebres de cola blanca (Lepus townsendii) y varias especies de conejos de cola de algodón (Sylvilagus spp). Las liebres (Lepus spp.) son particularmente importantes para el paisaje ecológico y económico del oeste de América del Norte debido a que su abundancia influye en el éxito reproductivo y en las tendencias poblacionales de depredadores como los coyotes (Canis latrans), linces (Lynx rufus) y una serie de especies rapaces. En este artículo revisamos la literatura relacionada con las liebres de cola negra y cola blanca que comprenden más de 170 artículos publicados en periódicos y revistas, notas, informes técnicos, actas de conferencias, trabajos y tesis académicos, y otra literatura que data de finales del siglo XIX hasta la actualidad. Nuestro objetivo es presentar información que asista a quienes trabajan en áreas de investigación y gestión, particularmente con especies protegidas de aves rapaces tales como el águila real y los mamíferos depredadores, y en relación al monitoreo ecológico. Clasificamos las fuentes bibliográficas como 1) información general sobre las especies de liebres, 2) liebres de cola negra o 3) ecología e historia natural de liebres de cola blanca, o 4) métodos de monitoreo. Estas categorías, en especial la 2), 3) y 4) se subdividieron según correspondía. La revisión también produjo diferentes tablas sobre las tendencias demográficas, los hábitos alimenticios, la densidad en de diferentes hábitats y el crecimiento y desarrollo de las liebres. Las liebres de cola negra y de cola blanca son ecológicamente similares en cuanto al comportamiento general, el uso de formas, parásitos y hábitos alimenticios; además ambas son presas de depredadores similares, pero difieren en cuanto a sus preferencias de hábitat. Mientras que la liebre de cola negra habita tierras agrícolas, desiertos y matorrales, la liebre de cola blanca se asocia a praderas, tundras alpinas y estepas-artemisa. Son frecuentemente consideradas abundantes, la abundancia de liebres al

\footnotetext{
${ }^{1}$ U.S. Geological Survey, Western Ecological Research Center, 160 N. Stephanie St., Henderson, NV 89074

2Present address: Department of Geography, University of Nevada, 1664 N. Virginia Street, Reno, NV 89557.

${ }^{3}$ U.S. Fish and Wildlife Service, 2321 West Royal Palm Rd., Suite 103, Phoenix, AZ 85201.

${ }^{4}$ School of Life Sciences, Arizona State University, Box 874501, Tempe, AZ 85287-4501.

5E-mail: msimes@usgs.gov
} 
oeste de América del Norte fluctúa temporal y espacialmente. También revisamos los métodos utilizados para investigar las poblaciones de liebres, incluyendo los transectos lineales, los transectos transversales, los conteos desde vehículos, los conteos de parcelas, colecciones, conteos de carreteras, estudios de marca/recaptura y estudios con radio telemetría. Nuestra revisión de la literatura de las liebres ilustra una serie de deficiencias en nuestro conocimiento sobre las liebres en general. Como ejemplo, podemos decir que se carece de una descripción cuantitativa detallada de las preferencias de hábitat, al igual que ocurre con el conocimiento de las interacciones entre especies simpátricas de liebres. Incluso la existencia del "ciclo" de la liebre, a menudo citado, es un tema de debate. Los métodos de monitoreo generalmente no son eficaces o exactos en la estimación de la densidad o la abundancia de liebres. Además, hay poca información sobre las liebres en el desierto de Mojave, no tenemos conocimiento real del ámbito hogareño, las preferencias de hábitat y la dinámica poblacional o la demografía en esta región.

Jackrabbits (Lepus spp.) are important components of the ecological and economic landscape of western North America because they are prey for a variety of predators including coyotes (Canis latrans) (Clark 1972), kit foxes (Vulpes macrotis), bobcats (Lynx rufus), Golden Eagles (Aquila chrysaetos), and other raptors (Best 1996). Jackrabbits also exert significant influence on rangeland conditions and agricultural activities (e.g., Vorhies and Taylor 1933, Currie and Goodwin 1966). This review primarily considers black-tailed jackrabbits (Lepus californicus) and white-tailed jackrabbits (Lepus townsendii) as prey species important to a number of predators including the Golden Eagle (Carnie 1954, Olendorff 1976, Bloom and Hawks 1982, Collopy 1983, Steenhof and Kochert 1988, Bates and Moretti 1994, Steenhof et al. 1997). Further rationale for the focus on these species is their widespread distribution compared to the limited distribution of the antelope jackrabbit (Lepus alleni) and white-sided jackrabbit (Lepus callotis) in the western United States. Measuring the abundance and distribution of jackrabbits has been central to previous work and is equally relevant to current issues about habitat quality for Golden Eagles and other protected raptor species. This literature review is intended to streamline information gathering and survey prioritization for those investigating western Leporidae, particularly in the context of prey surveys for raptors. In the western United States, black-tailed jackrabbits may be the primary prey for Golden Eagles, with other leporids, such as white-tailed jackrabbits and cottontail rabbits (Sylvilagus spp.), also being important (Olendorff 1976). Information about factors influencing availability and abundance of jackrabbits spatially and/or temporally can therefore provide insight into Golden Eagle habitat quality and management.

The genus Lepus, to which all hares and jackrabbits belong, is represented by 9 species in North America, including 6 jackrabbits. In the western United States, there are 4 jackrabbit species: the black-tailed jackrabbit, with 2 to 15 subspecies reported (Flinders and Chapman 2003); the white-tailed jackrabbit, with 2 subspecies (Lim 1987); the white-sided jackrabbit, with 2 subspecies (Best and Henry 1993a); and the antelope jackrabbit, with 3 subspecies (Best and Henry 1993b). Blacktailed jackrabbits and white-tailed jackrabbits have the largest distributions. Within the United States, antelope jackrabbits and whitesided jackrabbits are present only in south central Arizona and southwestern New Mexico, respectively. Primary residency for the antelope jackrabbit is the western coast of Mexico, including portions of the states of Sonora, Sinaloa, Chihuahua, Durango, and Nayarit; while the white-sided jackrabbit is present in parts of Chihuahua, Durango, and Sonora and most of central Mexico south to the states of Oaxaca and Guerrero (Nelson 1909, Best and Henry 1993a, 1993b). Two jackrabbit species are endemic to Mexico. The black jackrabbit (Lepus insularis) is isolated on Espiritu Santo Island, Gulf of California, and the Tehuantepec jackrabbit (Lepus flavigularis) is confined to the Isthmus of Tehuantepec (Cervantes 1993, Thomas and Best 1994).

The black-tailed jackrabbit is a generalist species with a wide breadth of suitable habitat characteristics and has been observed at elevations ranging from below sea level to over $3600 \mathrm{~m}$ and across a broad range of vegetation communities (McAdoo and Young 1980, Best 1996). Previous investigations of the blacktailed jackrabbit have considered the species' predator-prey interactions, importance to and relationships with breeding raptors, demography, movements, reproduction, population dynamics, and impacts to crops and rangelands (Bronson and Tiemeier 1958a, Lechleitner 1959a, Gross et al. 1974, Smith et al. 1981, Steenhof et 1997, Stoddart et al. 2001, Smith 


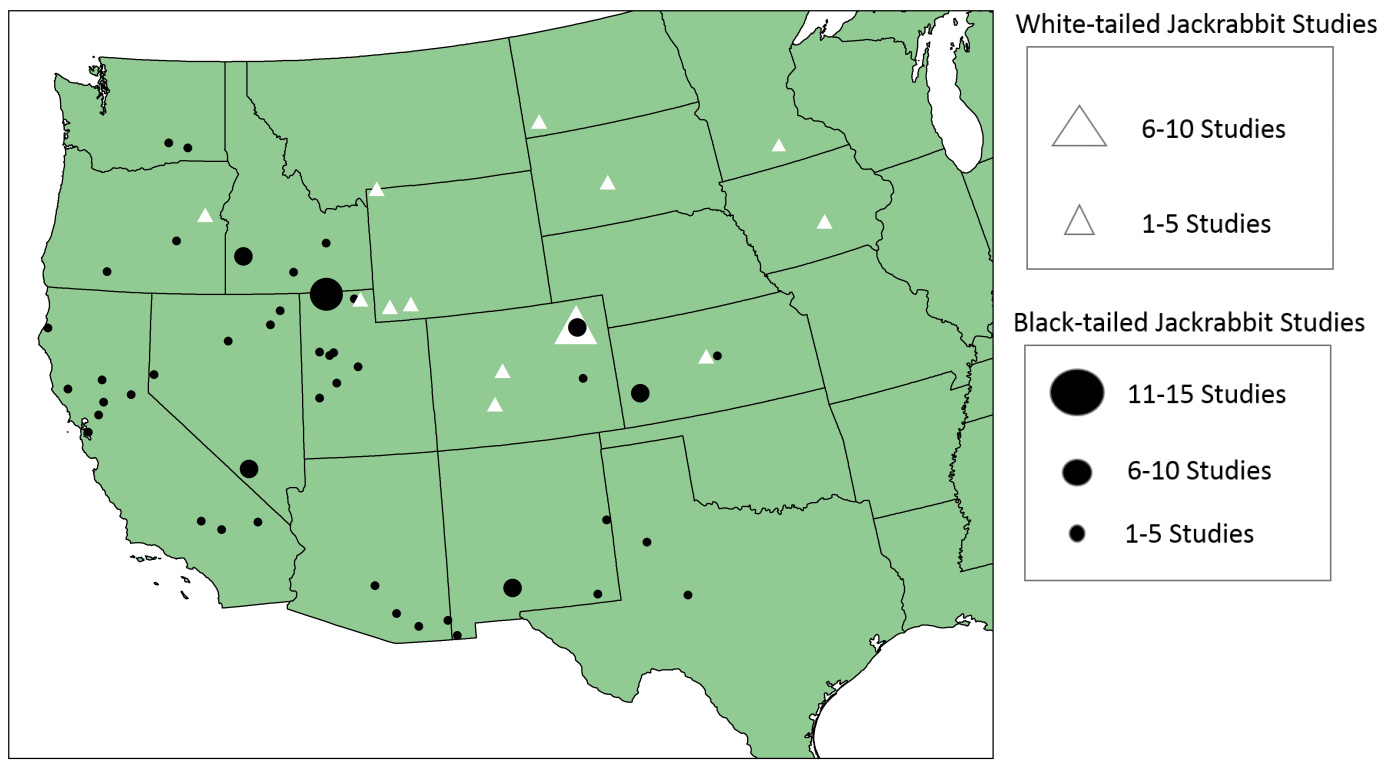

Fig. 1. Map of previous investigations into jackrabbit ecology and physiology.

et al. 2002). Studies of black-tailed and whitetailed jackrabbits extend across the American West; however, both species are understudied on the Colorado Plateau, and white-tailed jackrabbits are understudied west of the Rocky Mountains and in the Great Basin (Fig. 1). Much of the previous research on jackrabbits focused on the black-tailed jackrabbit as an indicator species for radioactive contamination from nuclear reactor and weapons testing during the last century throughout the western United States (Hayden 1962, French et al. 1965, Turner et al. 1966, O'Farrell and Gilbert 1975). Although over 275 journal articles, technical reports, monitoring reports, dissertations, theses, and notes have been published concerning jackrabbits (a number of which appear in this review), aspects of jackrabbit ecology remain understudied, including jackrabbits' role in particular environments.

The white-tailed jackrabbit is not as well represented in the literature as is the blacktailed jackrabbit, largely owing to the lack of long-term studies such as those devoted to black-tailed jackrabbits in northern Utah (Gross et al. 1974, Stoddart et al. 2001, Bartel et al. 2008), Idaho (French et al. 1965, Bartel et al. 2008), the Desert Southwest (Vorhies and Taylor 1933), and the southern Great Plains
(Bronson and Tiemeier 1959, Bowen et al. 1960), or those in relation to the black-tailed jackrabbit as a prey species for raptors (Marzluff et al. 1997, Steenhof et al. 1997). As a consequence of this deficiency, the literature, recent investigations notwithstanding (see Tapia 2010, Schaible and Dieter 2011, Schaible et al. 2011, Ferguson and Atamian 2012, Dieter and Schaible 2012, 2014), is comparatively dated and uneven in coverage of white-tailed jackrabbit ecology, demographics, and population trends.

White-tailed jackrabbits occupy open habitats such as prairies (Donoho 1972, Flinders and Hansen 1973), alpine tundra (Hoeman 1964, Braun and Streeter 1968), and sagebrush steppe (Gunther et al. 2009), also occupying cropland over much of their range (Tapia 2010). Historically, white-tailed jackrabbit exhibited sharp population peaks, or irruptions (Mohr and Mohr 1936); and in the past when whitetailed jackrabbit were more abundant, the species shared a reputation with the black-tailed jackrabbit as an agricultural pest. Although often lacking in quantitative data, reports of white-tailed jackrabbit dating back to the late 19th and early 20th century portray a declining species across the majority of its distribution (Brown 1940, Schaible and Dieter 2011). 


\section{Morphology and Diagnosis of Black-TaILed AND White-TAILED JaCKRABBITS}

The black-tailed jackrabbit is most easily identified by its black tail extending into a short dark strip on the animal's rump, sandy gray-brown pelage, and large black-tipped ears. Black-tailed jackrabbits lack the pale ear tips and/or white sides of the antelope and white-sided jackrabbits. Black-tailed jackrabbits are smaller than white-tailed jackrabbits (Table 1), although both exist within the middle to upper end of the size range for North American lagomorphs. The white-tailed jackrabbit has similar background color to its black-tailed congener, but its white tail and lack of a prominent dark strip on the rump readily distinguish it. White-tailed jackrabbits have 2 different pelages: a grey-brown molt in summer and a white winter molt (Lim 1987). In Colorado, molt coloration varies geographically. In the northern portions of the species' range, where winter snow is more dependable, the winter pelage has a greater amount of white present. In comparison, near the southern limits of its distribution, the summer pelage is a paler version of the brown summer coat. In this southern Colorado population, winter molt takes place in October and November and returns to summer pelage in April and May (Hansen and Bear 1963).

\section{EVOLUTION AND TAXONOMY OF NorTh AMERICAN LEPUS}

The origin of the genus Lepus is generally placed in the Early Pleistocene or Late Pliocene with prior Leporidae genera present in North America during the Miocene and Oligocene (Dice 1929, Dawson 1958, White 1991). Fossils of the genus Lepus are present in paleontological assemblages in North America. The remains of black-tailed jackrabbits are found among the fossils collected in Crystal Ball Cave, Utah, dating to 23,000 years before present (ybp; Heaton et al. 1985). Determining prehistoric or Holocene distribution of white-tailed jackrabbits and black-tailed jackrabbits is problematic because skeletal materials are very similar and difficult to distinguish (Grayson 1977, 1987). White-tailed jackrabbits have larger skulls that are relatively arched, with shorter and deeper rostra; while black-tailed jackrabbits have flatter skulls, with narrower 
and shallower rostra. However, the crania are almost identical for the 2 species (Fitzgerald et al. 1994).

The phylogeny of selected extant species in the genus Lepus including the black-tailed jackrabbit and white-tailed jackrabbit, was described at length using the cytochrome $b$ gene in mitochondrial DNA (Halanych et al. 1999). These authors report a Palearctic origin for the genus with successive radiations across Beringia to North America and back again, leading to the current distribution of Lepus across North America, Eurasia, and Africa. Several clades exist in North America, with the white-tailed jackrabbit occurring with the arctic species Lepus othus (Alaskan hare) and Lepus arcticus (Arctic hare) and with the Old World species Lepus timidus (mountain hare). The black-tailed jackrabbit, L. callotis, and $L$. alleni are grouped together within the western American clade (Halanych et al. 1999). These recent genetic analyses confirm the closely related status of these species which was discussed in earlier research and based on skull characteristics. Anderson and Gaunt (1962) indicated that L. alleni and L. callotis diverged from an isolated ancestral population of blacktailed jackrabbits. However, recent data from studies using cytochrome $b$ genetic information suggest a common ancestor to both the black-tailed jackrabbit and the distinct whitesided jackrabbit clade (which contains the antelope jackrabbit, white-sided jackrabbit, and Tehuantepec jackrabbit), dating to approximately 1.2 mybp (Lorenzo et al. 2014).

\section{The Black-Tailed JackrabBit}

\section{Ecology}

Jackrabbits rely on their speed, agility, and crypsis to escape or avoid predators. Young jackrabbits primarily rely on crypsis and their lack of scent to evade predators. Black-tailed jackrabbits also use ear flashing to evade predators, a behavior involving a rapid changing of ear positions while running to confuse predators. Other jackrabbit species exhibit similar alarm signal behaviors, flashing lightcolored body parts while escaping predators (Kamler and Ballard 2006).

Black-tailed jackrabbits are active in late afternoon through night, with little activity occurring during the morning and daylight hours; although in winter, activity may continue through the early morning (Rusch 1965, Knowlton et al. 1968, Smith 1990). Blacktailed jackrabbits spend much of the day in resting sites, termed forms, that often occur beneath shrubs or in areas of taller and denser vegetation, and move to feeding areas during the evening (Vorhies and Taylor 1933, Jurgensen 1962, Costa et al. 1976). Costa et al. (1976) found that between $49 \%$ and $57 \%$ of the jackrabbit's 24-h activity period was spent in forms or resting generally during daylight hours. Between $14 \%$ and $19 \%$ of the time was spent feeding, usually after dark. The forms are 15-45 cm long, 7-20 cm wide, and 0-10 cm deep (Vorhies and Taylor 1933, West et al. 1961). Form depth and orientation vary across the species distribution for black-tailed jackrabbits. In the Mojave Desert, forms may be gradually extended into shallow burrows that offer cover on the hottest of days (Costa et al. 1976). In Utah, $88 \%$ of forms in summer tended to be shaded, while in winter only $36 \%$ of forms were shaded (Rusch 1965). Jackrabbit fidelity to forms is low, and any given form may be used only once or several times. In Kansas, only $35 \%$ of forms were used more than 4 times, and the animals more frequently constructed new forms rather than clean or repair old ones (West et al. 1961).

The cyclic nature of some leporid populations can influence reproductive success of their predators, which include bobcats (Knick 1990), coyotes (Cypher et al. 1994, Bartel et al. 2008), and Golden Eagles (Steenhof et al. 1997). Although the existence of true cyclic patterns in small mammal populations has been debated (Krebs 1996), a number of authors report cyclic patterns for the blacktailed jackrabbit populations in the northern Great Basin (Eberhardt and Van Voris 1986, Steenhof et al. 1997, Bartel et al. 2008). Bartel et al. (2008) reported that 3 complete cycles observed from the early 1960s to the mid1990s in northern Utah had a periodicity of 10-11 years. In years of high jackrabbit abundance, the hares may act as buffer species alleviating to some degree the predation pressure on domestic stock (McAdoo et al. 2004). Large multiyear population increases such as those observed in the early 1980s appear to be broadly synchronous across the Great Basin (Bartel et al. 2008; Table 2). 

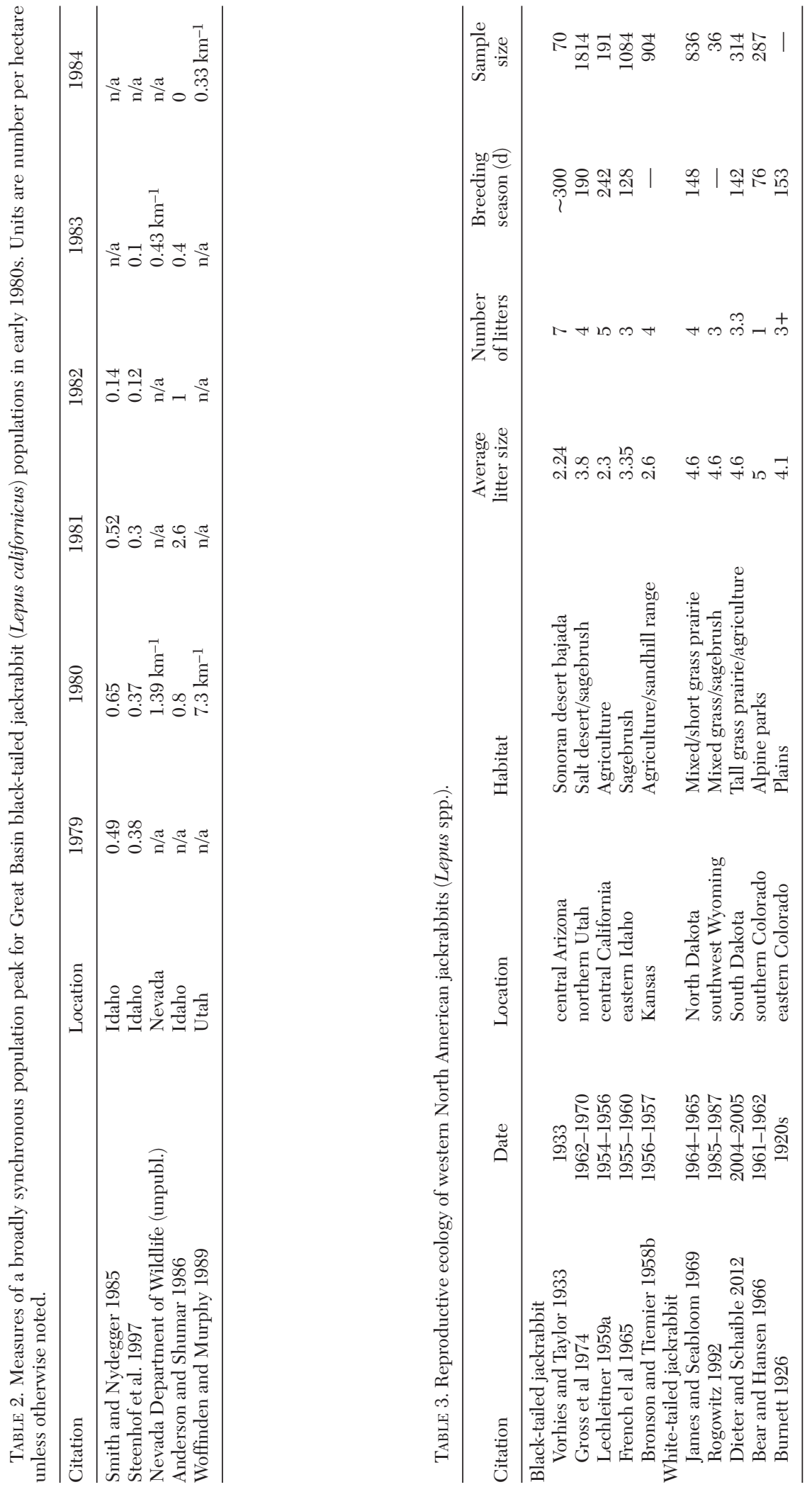


\section{Reproductive Behavior and Development of Young}

Depending on location, black-tailed jackrabbit reproduction can occur at almost any time of the year, with the breeding season being shorter in regions with a longer season of cold weather (French et al. 1965, Gross et al. 1974). During milder years, breeding activity may take place earlier than expected (Esch et al. 1959). In general, most breeding occurs during the first half of the year (Bronson and Tiemeier 1958b, Gross et al. 1974). In Arizona, breeding activity was observed in 10 to 11 months of the year (Vorhies and Taylor 1933; see Table 3), though few pregnant females were observed after June (Vorhies and Taylor 1933). This north to south increase in length of the breeding season is not absolute. At the Nevada National Security Site in the Mojave Desert of southern Nevada, breeding activity of black-tailed jackrabbits was observed to last from December to April (Hayden 1966b).

The breeding behavior of black-tailed jackrabbits involves chasing, circling, and various approaches by both sexes, culminating in copulation and multiple subsequent matings (Lechleitner 1959a, Blackburn 1973). Female black-tailed jackrabbits exhibit antagonistic behavior toward approaching males outside of estrus cycles (Lechleitner 1959a). The average gestation period for black-tailed jackrabbits as reported in the Central Valley of California is 43 days (Lechleitner 1959a). During a study of the growth and development of black-tailed jackrabbits in Utah, a female produced successive litters every 38-44 days (Goodwin and Currie 1965). Some anomalies have been identified, such as twinning, mummified extrauterine fetuses, and transmigrating ova (Evans and Griffith 1972). As with all Lepus species, the black-tailed jackrabbit produces precocial young that are fully furred with eyes open at birth. Observations of jackrabbit nests are rare; as a result, this aspect of their biology is poorly understood. The nests of jackrabbits, are reported to be hair-lined, bowl-shaped forms often under vegetation or a thin layer of soil (Vorhies and Taylor 1933). Historically, the most frequent nest observations have been made by farmers while plowing fields (Vorhies and Taylor 1933). Litter size varies greatly across the distributional range, though in general between 1 and 6 young are produced (Table 3; Gross et al. 1974). The average num- ber of young varies with the timing of the litter during breeding season. Lechleitner (1959a) observed that the number of young per litter peaked at around 4 in April but was only 1 in January and August. This variable litter size was also noted in Utah and Idaho, where peak litter size occurred in May (French et al. 1965, Gross et al. 1974).

Observations on neonatal black-tailed jackrabbits are limited due to the secrecy of the females and cryptic nature of young. Young jackrabbits remain in forms to be nursed at night, and females may return wandering young to the original birthing/nesting site (Stoddart 1984). The defense strategy of young hares usually consists of motionless hiding followed by slow movement once the hare is encountered by an observer, although defensive posturing described as spitting and boxing has also been observed (Vorhies and Taylor 1933, Haskell and Reynolds 1947). The young in captive-raised jackrabbit litters were observed to incorporate grass into their diet at 2-3 weeks of age before quickly transitioning to foraging for themselves (Haskell and Reynolds 1947, Goodwin and Currie 1965). Though uncommon, small amounts of milk have been documented in the diet of young jackrabbits up to 16 weeks of age (Sparks 1968, Flinders and Chapman 2003). Jackrabbits in northern Utah's Curlew Valley attained $90 \%$ of average adult measurements by the age of 10 weeks, while having only $65 \%$ of adult weight (Table 4; Goodwin and Currie 1965).

\section{Jackrabbits and Shrub Cover}

Shrubs are important to jackrabbits for cover and seasonal forage. Jackrabbit foraging is positively correlated with proximity to cover, and this positive correlation may reduce predation risk (Longland 1991, Marín et al. 2003). The preference of jackrabbits to use areas with shrub cover is evident in track surveys conducted in northeastern Colorado, where concentrations of jackrabbit activity were observed in areas of abundant shrub cover (Donaho 1971). Likewise, black-tailed jackrabbits in northern Mexico responded positively to shrub density, as opposed to sympatric white-sided jackrabbits, which were found in grassland with less shrub encroachment (Desmond 2004). The correlation between jackrabbits and shrub cover was also observed during jackrabbit foraging activity on agricultural 


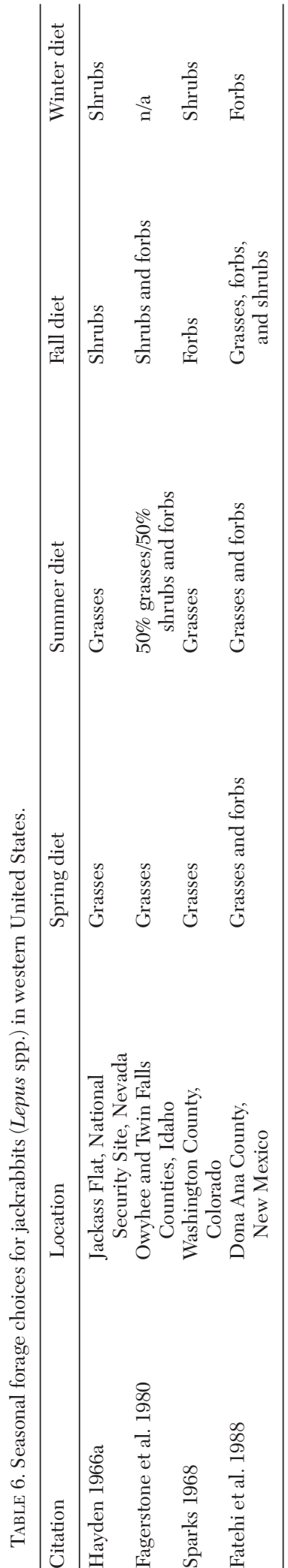

lands in Kansas, where crop damage by jackrabbits was restricted to fields adjacent to daytime resting areas in sand-hill rangeland (Bronson and Tiemeier 1958a). Vorhies and Taylor (1933) report a number of instances when sizable portions of cropland including alfalfa and cotton were destroyed by jackrabbits during drought years in southern Arizona. Most of this damage occurred on farms adjacent to brushland and within $800 \mathrm{~m}$ of that cover. Similarly, jackrabbit pellet density decreased when the distance from cover was $>200 \mathrm{~m}$ in a crested wheatgrass (Agropyron desertorum) seeding surrounded by sagebrush (Artemisia spp.) in central Nevada (McAdoo et al. 1987).

Although the black-tailed jackrabbit occurs in sagebrush habitats over much of the Great Basin, because of its broad elevational breadth, this jackrabbit also occurs in many vegetation types outside Artemisia distributions (Table 5; Fautin 1946, Chew and Chew 1970). Jackrabbits in Arizona built their forms in areas dominated by creosote and mesquite (Prosopis spp.) habitats (Brown and Krausman 2002). An association with various Atriplex species has also been noted in multiple studies (Fautin 1946, Currie and Goodwin 1966, McAdoo and Young 1980, Hunter 1987).

\section{Food Habits}

Dietary choices made by black-tailed jackrabbits are wide-ranging and general. Blacktailed jackrabbits subsist mainly on grasses and forbs in the spring and early summer, and they rely more heavily on perennial shrubs and/or cacti in late summer, fall, and winter (Table 6). This dietary shift is thought to be driven by water and/or nutritional needs. In southern Nevada, jackrabbits preferentially fed on shrubs (e.g., Atriplex spp., Ambrosia spp., Chrysothamnus spp., and Larrea tridentata) located in the more mesic microhabitats, alleviating some water stress (Hunter 1987). During a drought that occurred across burned areas of Joshua Tree National Park in southern California, jackrabbits resorted to stripping the periderm (bark) from Joshua tree (Yucca brevifolia) trunks (DeFalco et al. 2010). Jackrabbits often move to areas of more succulent vegetation (i.e., better quality rangeland or agricultural fields) during their nightly feeding before retreating to rangelands during the day. These movements were frequently observed to be 1.6-3.2 km long, with occasional 
forays (ranging to $16 \mathrm{~km}$ ) to alfalfa fields in dry seasons (Vorhies and Taylor 1933). Of particular significance, winterfat (Krascheninnikovia lanata) is an important forage plant (Currie and Goodwin 1966, Hayden 1966a, Johnson and Anderson 1984, Nydegger and Smith 1984, Anderson and Shumar 1986). This plant occurs throughout all contiguous states west of the Rocky Mountains and into Canada.

Black-tailed jackrabbits have, or historically had, a considerable impact on agriculture in the West, particularly in times of drought, often causing large amounts of economic damage. In Idaho, jackrabbits exhibited significantly higher densities near cultivated crops than on rangeland (Fagerstone et al. 1980). During the winter of $1981 / 82$ an estimated 10 million dollars of agricultural damage was caused by black-tailed jackrabbits in Idaho; other western states were similarly affected (Evans et al. 1982). The planting of buffer or "catch" crops such as rye (Lewis 1946) or potatoes (Fagerstone et al. 1980) may decrease the amount of damage done to crops by black-tailed jackrabbits.

\section{Diseases and Parasites}

The black-tailed jackrabbit is a primary host to a number of microparasites and a carrier of several diseases (Best 1996). Of particular pertinence to human health are tularemia (Francisella tularensis), Q fever (Coxiella burnetii), Lyme disease (Borrelia burgdorferi), plague (Yersinia pestis), and Rocky Mountain spotted fever (RMSF; Rickettsia rickettsia) (Eberhardt and Van Voris 1986, Henke et al. 1990). These diseases have been monitored in jackrabbit populations throughout the western United States, and with the exception of RMSF, most diseases have a fairly low occurrence within the population (Table 7). These diseases can all be spread via invertebrate vectors such as fleas, ticks, and lice; however, tularemia and Q fever are also spread through direct contact and/or aerosol exposure. Rocky Mountain spotted fever is often reported in the sera of jackrabbits (Table 7; Philip et al. 1955, Eberhardt and Van Voris 1986). Research at the Dugway Proving Grounds in Utah documented increases in the occurrences of diseases during population declines (Eberhardt and Van Voris 1986). Eight rabbit carcasses at Gray Lodge Waterfowl Management Area in California exhibited 
external signs of tularemia; however, these were not further examined (Lechleitner 1958). In a more intensive investigation of diseases within this population, 142 jackrabbits were examined for diseases. However, none tested positive for tularemia (Lechleitner 1959b). The propensity for transmission of diseases found in jackrabbit populations to humans is low. Transmission via invertebrate vectors is possible, but the improper handling of infected lagomorphs by hunters is the most likely mode of transmission to humans (Flinders and Chapman 2003).

In addition to diseases related to microparasites, black-tailed jackrabbits host a number of mesoparasites, with many studies reporting high incidences of parasitism. In the Picacho Mountains of Arizona, black-tailed jackrabbits had fleas (30.5\%), ticks (Haemaphysalis leporispalustris, 50\%), tapeworms (Taenia multiceps, 8.3\%), and cestodes (Cittotaenia, 11\%) (Lipson and Kraussman 1988). In Northern California, up to $78 \%$ of tested rabbits had nematode infestations and between $17 \%$ and $22 \%$ had ectoparasites such as ticks and lice (Clemons et al. 2000). Black-tailed jackrabbits have harbored populations of various soft- (Otobius lagophilus) and hard-bodied ticks (Dermacentor parummapertus and D. andersoni) (Philip et al. 1955). Near the Great Salt Lake Desert in Utah, ticks were common on jackrabbits during spring and summer, with 1 specimen harboring 420 individual nymph, larvae, and adult individuals (Rosasco 1957). In Arizona, ticks were abundant on almost every sampled jackrabbit during the summer months but disappeared from jackrabbits in September or October (Vorhies and Taylor 1933). In central Nevada, larvae of Cuterebra spp. (bot fly) were common (Philip et al. 1955). Occurrences of Cuterebra larvae can be highly variable. Reports indicate that the rump, neck, and head are usually most heavily parasitized by Cuterebra larvae. In some years, almost all rabbits may be infected, sometimes extensively, while in other years the larvae may be exceedingly scarce (Vorhies and Taylor 1933).

\section{Density and Demography}

Black-tailed jackrabbits exhibit wide population density fluctuations, particularly in the northern Great Basin. These fluctuations have been broadly studied and reported to occur in periods of approximately $7-11$ years (Gross et al. 1974, Bartel et al. 2008). The causes of these increases and subsequent declines in abundance are poorly understood. Various hypotheses include predation pressure (Clark 1972, Wagner and Stoddart 1972), parasitism and diseases such as tularemia (Phillip et. al. 1955, Eberhardt and Van Voris 1986), and forage availability (Clark and Innis 1982). Alone, none of these hypotheses adequately explain the causes for population fluctuations in black-tailed jackrabbits. In Kansas, New Mexico, northern Mexico, Arizona, and southern Nevada, the species exhibits smaller fluctuations contingent upon local environmental conditions (i.e., drought), rather than longterm population oscillations (Vorhies and Taylor 1933, Bronson and Tiemeier 1959). Blacktailed jackrabbits can reach extreme or plague densities during these fluctuations, notably during droughts. The most famous example of these concentrations (up to 1.86 jackrabbits per hectare) took place during the Dust Bowl in the southern plains (Wooster 1935, Bronson and Tiemeier 1959). Later in the early 1950s, black-tailed jackrabbit densities up to 1.72 jackrabbits per hectare, with a maximum count of 34.6 per hectare, were observed in rangeland near agricultural fields during a Kansas drought (Bronson and Tiemeier 1958a).

Studies of the effects of precipitation and drought on jackrabbit population fluctuations have also led to conflicting conclusions, leaving no single clear relationship between weather and population peaks. In southern New Mexico's Chihuahuan Desert, black-tailed jackrabbit densities were not positively correlated with either annual rainfall or plant growth (Lightfoot et al. 2010). On the contrary, in the Mojave Desert of southern Nevada, population trends of jackrabbits were positively correlated with increased precipitation during the previous year (DOE 1996). It has been proposed that jackrabbit population levels may increase due to reduced young rabbit mortality during periods of reduced precipitation accompanying droughts (Wooster 1935, Bronson and Tiemeier 1959); however, several other theories (e.g., immigration of rabbits from the surrounding rangeland to more productive resources such as agricultural fields) may also explain these observations. Thus there are at least 3 different conclusions regarding the importance of precipitation: (1) that precipitation has little effect on 


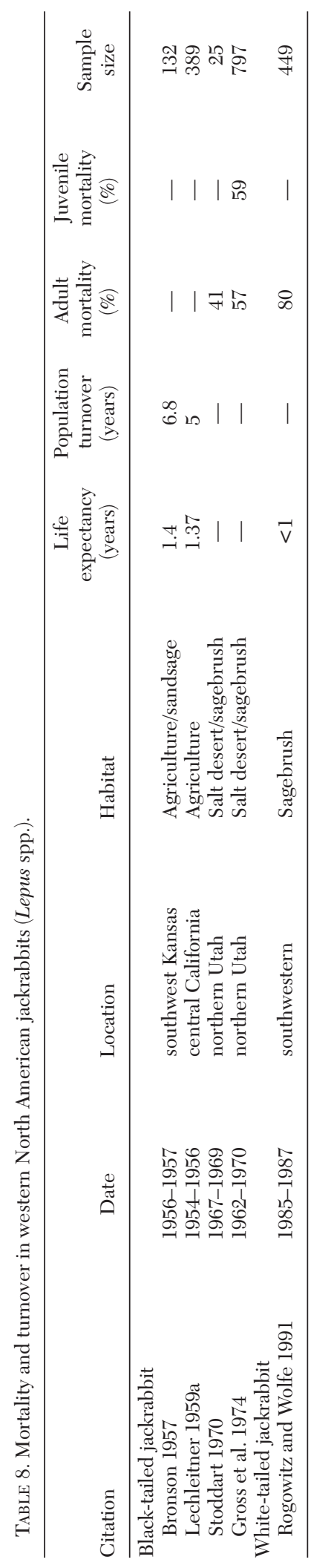

population fluctuations; (2) that increased precipitation is associated with population increases; and finally, (3) decreased precipitation is associated with population increases. However, these conclusions were drawn from 3 widely scattered areas and involve different population responses to different climatic conditions, illustrating the adaptability of the black-tailed jackrabbit and the need for further study. Although precipitation undoubtedly has some influence on jackrabbit abundance, there are not enough quantitative data to determine what influence precipitation may have on population trends in the black-tailed jackrabbit.

Weather phenomena affect the behavior and survivorship of jackrabbits. In Idaho, high winds decreased activity levels of jackrabbits, with the most pronounced decrease in winter (Smith 1990). High wind conditions in conjunction with food stress brought on by adverse weather events (i.e., flooding or blizzards) may be associated with increased jackrabbit mortality (Lechleitner 1958, Stoddart 1985, Smith 1990). For example, a 4-day February blizzard in Utah resulted in a jackrabbit mortality rate for the 4-day period of 0.339 , which is 13 times greater than the rate of 0.026 for January and the remainder of February (Stoddart 1985). However, it was noted that this and similar mortality events are probably rare (Stoddart 1985). Black-tailed jackrabbits also display seasonal density changes, wherein the young rabbits increase densities through the spring and summer then decline to lower fall and winter densities because of high mortality rates (Hayden 1966b, Gross et al. 1974, Davis et al. 1975, Sosa Burgos 1991, DOE 1996).

Population TURNOver.-Mortality rates and estimated population turnover rates for black-tailed jackrabbit populations vary (Table 8). Studies demonstrate high rates of mortality from weather, shock, hunting, and predation (Lechlietner 1958, French et al. 1965, Stoddart 1970, Wagner and Stoddart 1972, Stoddart 1985). The mean lifespan of a black-tailed jackrabbit at Gray Lodge Waterfowl Management Area, California, was estimated to be approximately 1.37 years (Lechleitner 1959a), and the population was estimated to have turned over in approximately 5 years. Lechleitner speculated population turnover might be faster, as his data set undersampled jackrabbits $<3$ months of age. This undersampling 


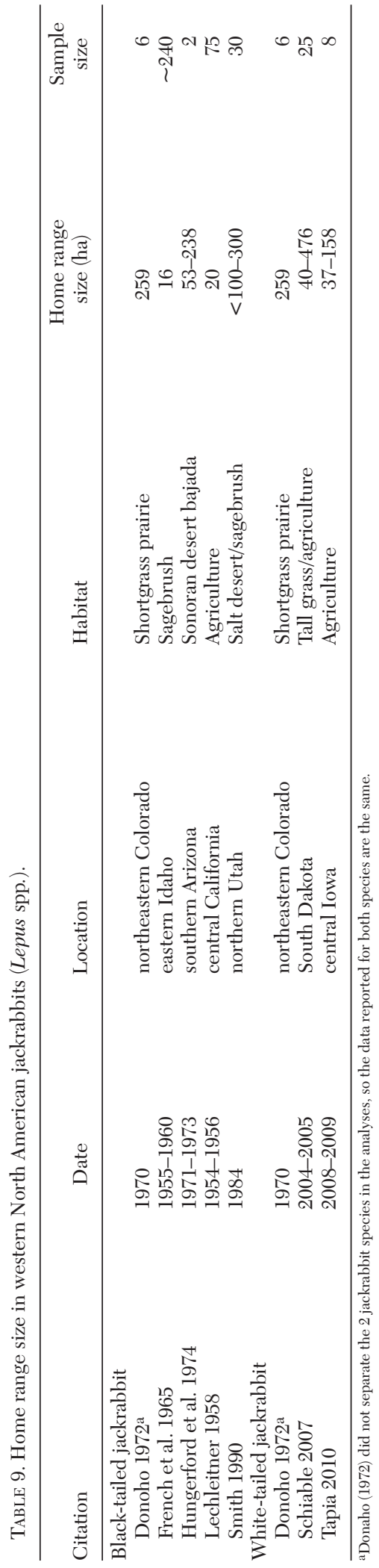

of jackrabbits 3 months and younger is a common occurrence (Gross et al. 1974), as others have noted few young animals in their collections (Bronson 1957). Fewer than $10 \%$ of marked animals in an Idaho study were alive after 10 months and just $1.8 \%$ were known to be alive after 1.9 years (French et al. 1965). However, juvenile mortality has been estimated to be similar to that of adults in some populations (Table 8; Gross et al. 1974, Flinders and Chapman 2003). In northern Utah, adult mortality averaged $57 \%$ across 9 years but was highly variable, ranging from $23 \%$ to $87 \%$ annually (Gross et al. 1974).

\section{Home Range and Seasonal Movement}

Within the black-tailed jackrabbit's wide geographical distribution, home-range size varies considerably relative to resource availability and local environmental conditions (Vorhies and Taylor 1933, Lechlietner 1958). In general, home range size varies from $<50$ ha to 300 ha (Table 9). In the Curlew Valley of northern Utah, home ranges were generally elliptical in shape, and males had larger home ranges than females (Smith 1990). At Gray Lodge Waterfowl Management Area in California, females had larger home ranges than males in summer and fall (Lechleitner 1958). Using ocular observations, trap/retrap data, and radiotelemetry, several studies found that black-tailed jackrabbit home ranges were relatively stable (Leichleitner 1958, Hungerford et al. 1974). Jackrabbits demonstrated site fidelity by returning to previously occupied home ranges after extended absences caused by flooding (Lechleitner 1958).

Black-tailed jackrabbits exhibit localized seasonal movements, at least in the northern portions of their range. Radiotelemetry established that jackrabbits in northern Utah moved to wintering areas of greater vegetation cover, generally moving toward denser stands of greasewood (Sarcobatus) or sagebrush (Smith 1990). Black-tailed jackrabbits were recorded moving more than $5 \mathrm{~km}$, and much of that movement seemed to be seasonally related (Smith et al. 2002). Winter concentrations of jackrabbits were also observed in the Curlew Valley, where marked animals traveled as far as $17 \mathrm{~km}$ (Rusch 1965). At the Idaho National Engineering Laboratory (INEL), home ranges were initially estimated based on observations of limited movement within 
a marked population (French et al. 1965); however, later surveys found long-distance movement in up to $50 \%$ of the INEL jackrabbit population (Bartel et al. 2008). Jackrabbits can and do undertake long-range movements or dispersal. A marked female was killed 17 weeks after she was marked some $45 \mathrm{~km}$ from her release point in eastern Idaho (French et al. 1965).

Black-tailed jackrabbits can also move in relation to local climatic or habitat conditions. Concentrations of jackrabbits have been noted surrounding standing water in the Mojave Desert (Hayden 1966b) and in agricultural fields during droughts on the Southern Plains (Bronson and Tiemeier 1958a). Vorhies and Taylor (1933) anecdotally reference a number of instances in which either seasonal or resourcerelated movements are documented, including one instance of mass movement during a blizzard near Ontario, Oregon. Seasonal movements between wintering and summering areas, or to avoid adverse conditions, may affect demographic data interpretations (Bartel et al. 2008).

\section{The White-Tailed Jackrabbit}

\section{Ecology}

The white-tailed jackrabbit is ecologically similar to the black-tailed jackrabbit in many respects, including behavior, use of forms, parasites, food types, and predators; however, it differs in its preferred habitat. White-tailed jackrabbits occupy native prairies, open grassland, agricultural fields, alpine tundra, and sagebrush/grassland foothills (Hoeman 1964, Braun and Streeter 1968, Lim 1987, Gunther et al. 2009). In eastern Colorado, white-tailed jackrabbits were generally more prevalent in grassland habitats than in habitats with greater concentrations of shrubs (Donoho 1972). In the Basin and Range of Idaho, Utah, and Nevada, as well as the Columbia Plateau, white-tailed jackrabbit distribution was confined to upper montane slopes. Similar to other jackrabbits, the white-tailed jackrabbit relies on its speed and agility to escape predators when its cryptic coloration fails (Fitzgerald et al. 1994, Gunther et al. 2009). Whitetailed jackrabbits are primarily crepuscular; however, when sympatric with black-tailed jackrabbits, they are generally more nocturnal in their activities (Flinders and Chapman 2003). The white-tailed jackrabbit exhibits similar seasonal food habits to black-tailed jackrabbits. Grasses and forbs are important during spring, summer, and fall; and shrubs are predominant dietary items during winter months (Bear and Hansen 1966, Flinders and Hansen 1971). Unlike the black-tailed jackrabbit, the white-tailed jackrabbit rarely causes widespread crop depredation losses (Johnson and Peek 1984).

\section{Diseases and Parasites}

The parasites and diseases of white-tailed jackrabbits are understudied. White-tailed jackrabbits are presumably subject to a similar retinue of diseases and parasites as blacktailed jackrabbits (Lim 1987). In a survey that tested 314 white-tailed jackrabbit livers collected throughout South Dakota for tularemia, only 14 had signs of abnormality and none tested positive for bacterial infections including tularemia; but a nematode parasite, Calodium hepaticum, was found in 4 of the livers (Schaible et al. 2011). Shultz and Rickard (1985) found various helminth parasites, including Mosgovoyia spp. and Taenia spp., in whitetailed jackrabbits from northern Colorado and southern Wyoming. In Canada, 8 white-tailed jackrabbits were minimally affected by parasites, with a total of only 2 ticks and a single flea found (Galloway 2012). Malignant tumors are also reported in the white-tailed jackrabbit; but these abnormalities were only reported because the infected animal was suspected of infecting domestic dogs, and such malignancies could be underreported in populations (Jardine et al. 2004).

\section{Reproductive Behavior and Development of Young}

The breeding season for white-tailed jackrabbits is from late February to mid-July in North Dakota (James and Seabloom 1969) and Wyoming (Rogowitz 1992) but occurs from March through August in southern Colorado (Fitzgerald et al. 1994). During years of milder winter weather, breeding began earlier than normal (Rogowitz 1992). Breeding behaviors are similar to that of the black-tailed jackrabbit and include approaches, chases, and jumping; however, jumping behavior seem to be more pronounced among white-tailed jackrabbits (Blackburn 1973). The gestation period for white-tailed jackrabbits is between 30 and 42 days, and the variation may be influenced by 


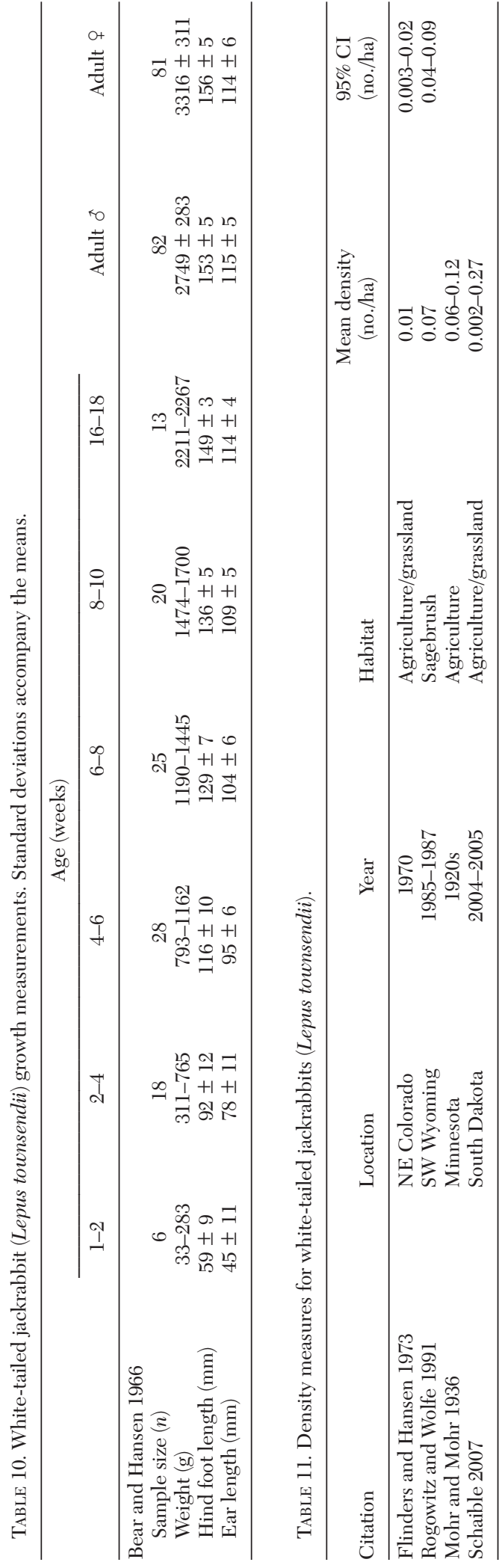

conditions in the northern portions of the species' range (Lim 1987). Synchronous breeding activity within populations was observed throughout the species' range. In North Dakota, 4 well-defined breeding peaks were observed (Table 3; James and Seabloom 1969). The young white-tailed jackrabbits develop similarly to their black-tailed congeners, with body measurements such as ear and hind foot length approaching adult dimensions before the animals attain adult mass (Table 10).

\section{Density and Demography}

The white-tailed jackrabbit exhibits, or at least historically exhibited, periodic fluctuations in abundance and density. Baseline densities for the species are reported throughout its range east of the Continental Divide; however, comparatively little information is published regarding the species in the Great Basin and western portions of its distribution (Table 11). One such population peak was observed at Rapidan, Minnesota, where jackrabbit densities were estimated to be between 19 and 31 jackrabbits per square kilometer in 1933-1934 (Mohr and Mohr 1936). A similar though greater irruption occurred in Hettinger County, South Dakota, in the winter of 1924 when densities up to 1.35 jackrabbits per hectare were reported (Mohr and Mohr 1936). In Wyoming, typical life span of the whitetailed jackrabbit was estimated at $<1$ year (Table 8 ), and only $12 \%$ of collected animals in this population were $>1.5$ years old (Rogowitz and Wolfe 1991).

\section{Home Range}

White-tailed jackrabbit home range estimates, as with many aspects of the species' ecology, are available mostly from the eastern portion of the distribution (i.e., Colorado, Iowa, and South Dakota). Home ranges of jackrabbits in central Iowa farmland expand and contract throughout the year (Tapia 2010). In South Dakota, average home ranges for male and female white-tailed jackrabbits were $1.34 \mathrm{~km}^{-2}$ and $1.09 \mathrm{~km}^{-2}$, respectively; and actual area used varied (Table 9; Schaible 2007). The wide variation found in jackrabbit home range size is partially explained by habitat: jackrabbits in agricultural habitats tend to have smaller home ranges than those on native rangelands (Schaible 2007). 
Population Declines and Changes in Distribution

During the last 150 years, agricultural land conversions have simultaneously damaged and enhanced habitat for the white-tailed jackrabbit. In areas where grasslands were converted to agriculture, the distribution of white-tailed jackrabbits declined. Conversely, where agricultural development opened up unsuitable shrublands and forests, the distribution of white-tailed jackrabbits expanded into the newly available habitat. Early settlers and naturalists reported changes in jackrabbit distributions, with black-tailed jackrabbits supplanting white-tailed jackrabbits in many areas (Couch 1927, Carter 1939, Brown 1940). A range shift has been reported, with the whitetailed jackrabbit becoming rare or extirpated in areas of Kansas (Brown 1940, 1947), Nebraska, Missouri (Watkins and Nowak 1973), Colorado (Burnett 1926), and Washington (Clanton and Johnson 1954) that it used to inhabit. Early settlers report that white-tailed jackrabbits were originally very common in Kansas and Colorado, while black-tailed jackrabbits were rare or nonexistent. In 1910, the white-tailed jackrabbit was considered more abundant than the black-tailed jackrabbit in eastern Colorado, but by the mid-1920s that trend had reversed (Burnett 1926). The same trend was concurrently noted in western Kansas, where white-tailed jackrabbits were common in the 1860s and decreased to being rare or absent by the 1920s while the blacktailed jackrabbit became common and widespread (Carter 1939). By the mid-20th century, the white-tailed jackrabbit was outnumbered 3:1 by the black-tailed jackrabbit in eastern Colorado (Donoho 1972). In Iowa, the whitetailed jackrabbit expanded its range as the native landscape was opened up for agriculture in the late 19th and early 20th century, then declined as agriculture practices shifted from grain farming to widespread corn cultivation (Tapia 2010). Leopold (1947) speculated that white-tailed jackrabbits were present in Wisconsin prior to 1840 , when the use of fire by Native Americans to keep prairie habitats open was halted; then as oak-hickory forest encroached, the species range receded. White-tailed jackrabbits subsequently expanded once again into Wisconsin as dairy farms and logging operations opened the land- scape in the late 19th and early 20th century (Leopold 1947, De Vos 1964).

Landscape alterations due to anthropogenic sources such as grazing are indicated as a cause in the decline of the white-tailed jackrabbit in other regions. In Washington, the loss of bunchgrass habitats due to overgrazing fostered the decline of white-tailed jackrabbits (Svilha and Svilha 1940). This widespread dynamic change in the species' distribution, coupled with the relative lack of detailed regional data, leaves much to be desired in interpreting the true distribution and status of the white-tailed jackrabbit. A decreasing trend in abundance was reported in South Dakota by Schaible and Dieter (2011). Investigations regarding reproductive and population characteristics (Dieter and Schaible 2012) and disease (Schaible et al. 2011) failed to illuminate a definitive cause for the decline of the white-tailed jackrabbit in that state. The perceived loss of the white-tailed jackrabbit in Yellowstone National Park (Berger 2008a, 2008b) caused much debate, though the conclusion was that the species still inhabited some areas in the northern portion of the park (Gunther et al. 2009). Changes in white-tailed jackrabbit distribution notwithstanding, most sources agree that the species is largely declining across its range. The species has declined to such a degree that some states, including Oregon and Washington, have curtailed its hunting (Oregon Department of Fish and Wildlife 2015, Washington Department of Fish and Wildlife 2014).

\section{JACKRABBITS AND HUMANS}

Jackrabbits have played an important role in human cultures throughout the archeological and historical records. Prehistoric North Americans used various leporid species of the Great Basin and Colorado Plateau (Schmitt et al. 2002), and the presence of leporid bones in the archaeofauna of sites across the Intermountain West show evidence of human consumption as well as the use of rabbits for tools and adornment (Schmitt 1995). Archeological investigations have detailed the collection of drive nets and leporid faunal remains from prehistoric sites, as well as depictions of rabbit drives in artworks in the Great Basin and Rio Grande River Valley (Shaffer and Gardner 1995). Archeologists use the lagomorph index, 
a metric based on jackrabbit and cottontail rabbit bones, to investigate a number of questions regarding prehistoric peoples in the southwestern United States. These include the effects of their agriculture and forestry practices, their hunting techniques, their harvest rates of leporids (Driver and Woiderski 2008), and even climate shifts that occurred during their time (Fisher 2012).

Reports of 16th-century Spanish explorers include descriptions of rabbit drives and hunting techniques among peoples of northern Mexico and the Pueblo Nations in the Rio Grande Valley (Palmer 1897). Reports from early Anglo-American explorers in the West detail rabbit drives in cultures from central Washington to California (McAdoo and Young 1980). As Europeans colonized the American West, much of the interaction between humans and jackrabbits was characterized by economic losses associated with agricultural depredation by rabbits. Overgrazing of livestock on former grasslands resulted in conversion to shrublands, and the conversion of rangeland to agricultural fields has been indicated in the increase of black-tailed jackrabbit abundance throughout many regions of the western United States, including the Great Plains, Desert Southwest, and Great Basin (Vorhies and Taylor 1933, Flinders and Hansen 1975, Bednarz and Cook 1984, Roundy et al. 1985, Hunter 1987, McAdoo et al. 1987, Daniel et al. 1993). To further complicate the interaction of jackrabbits with agriculture (as noted in the density and demography section for blacktailed jackrabbits), jackrabbit populations may be irruptive, with numbers driven by multiyear climatic phenomena, severe weather, or intra- and interspecific population pressures.

The Anglo response to jackrabbit irruptions was to consider the hares agricultural pests and competitors with domestic livestock (Palmer 1897, Vorhies and Taylor 1933, McAdoo and Young 1980). The reputation of black-tailed jackrabbits as pests was fortified when jackrabbit population irruptions and/or drought periods led to concentrations of jackrabbits around planted fields, sometimes resulting in extremely high densities. Because these irruptions occurred during times of drought, they were especially devastating economically (Palmer 1897, Wooster 1935, Brown 1940, Bronson and Tiemeier 1958, Brown and Carmony 2009, Brown 2012a, 2012b).
Although livestock grazing following European settlement may have initially generated habitat for jackrabbits, more than a century of livestock grazing subsequently reduced the quality and abundance of jackrabbit habitat within sagebrush across the Intermountain West and Great Basin. Livestock grazing facilitated the spread of highly flammable exotic grasses, such as cheatgrass (Bromus tectorum), which generated more frequent and severe large fires in sagebrush-dominated landscapes when compared to historical conditions. Fuel loads were lighter prior to the establishment of introduced grasses (Weddell 2001, Keane et al. 2008). Knick and Dyer (1997) concluded that wildfire from 1980 to 1992 within the sagebrush habitats of the Snake River Birds of Prey National Conservation Area (NCA) in southwestern Idaho likely caused a loss of black-tailed jackrabbit habitat via the damage or loss of sagebrush habitat compounded with the presence of fire-prone exotic grasses. Concurrent with the NCA study, studies evaluating Golden Eagle reproduction, diet, and movements identified fire as negatively affecting black-tailed jackrabbits and their habitat (Marzluff et al. 1997, Kochert et al. 1999). Across existing sagebrush cover types in the Great Basin of Nevada, Utah, and California and in sagebrush that encompasses southeastern Oregon, southern Idaho, and portions of northeastern California, Nevada, and western Utah, about $57 \%$ of the acreage is estimated to be at moderate or high risk of elimination over the next 30 years due to continued cheatgrass expansion (Miller et al. 2005). It is estimated that fire risk is $100 \%$ when there is $>45 \%$ cheatgrass land cover (Link et al. 2006).

Other Mediterranean grasses present similar fire risks in hot deserts and are of great concern to natural resource managers in the Mojave and Sonoran Deserts. Red brome (B. madritensis var. rubens), a close relative to cheatgrass, and split grass (Schismus spp.) have encroached widely into some hot desert shrub habitats over the past 150 years (Salo 2004). Desert wildfires have burned vast expanses of hot desert environment. For example, in 2005 over 750,000 acres were burned in a fire complex across parts of Nevada, Utah, and Arizona (Bauer et al. 2011). In addition to reducing habitat through increased fire risk, these winter annual grasses 
can cause widespread habitat change in some areas by reducing perennial plant cover (Shryock et al. 2015). The loss of habitat structure can affect small animal communities (Esque et al. 2003) including jackrabbits. However, little work has focused specifically on the role fires play in jackrabbit habitat and the consequences for potential prey-base changes on mesofauna and raptors such as the Golden Eagle.

Long-term livestock grazing is believed to be responsible for reducing fire frequency and increasing the respective densities of juniper (Juniperus spp.) within southwestern woodland and mesquite (Prosopis spp.) in desert grassland habitats (Wright et al. 1979, Van Auken 2000), causing a mixed response by different jackrabbit species. The increase in density of both juniper and mesquite has contributed to a reduction in overall wildlife abundance and diversity (Germano et al. 1983, Miller et al. 2005). An increase in woody vegetation within the Great Basin is attributed to decreased white-tailed jackrabbits and increased black-tailed jackrabbits (Gruell 1996). There are few studies evaluating the impacts on small mammal populations of increasing juniper densities (Miller et al. 2005). In the Animas and Playas Valleys of southern Hidalgo County, New Mexico, white-sided jackrabbits (Lepus callotis) declined by 65\% since 1976 . The decline may have been due to a $51.3 \%$ reduction in desert grassland habitat attributed to mesquite encroachment (Traphagen 2011). Black-tailed jackrabbits also declined in the same grasslands. In the desert grasslands of the Santa Rita Experimental Range in Pima County, Arizona, antelope jackrabbits (L. alleni) and black-tailed jackrabbits were most abundant when dense mesquite cover was reduced to provide openings, but they declined when mesquite was entirely removed (Germano et al. 1983). However, in undisturbed dense mesquite, black-tailed jackrabbit numbers were nearly identical to those in mesquite habitat with openings (Germano et al. 1983). In California, observations of jackrabbits increased in a mixed coniferous forest subjected to prescribed fire treatments as a consequence of the increased openness of the understory and newly available food resources (Amacher et al. 2011).

Efforts to control jackrabbit populations became common in several states throughout the 19th and early 20th centuries. Programs included bounties, rabbit drives, and poisoning. The payment of bounties on jackrabbits as a means of population control was a regularly used but short-lived method, as the bounty system frequently led to insolvent county governments and subsequent repeal of the bounties (McAdoo and Young 1980). Rabbit drives as a means of control remained in use at least until the early 1980s (Johnson and Peak 1984). The death toll of these eradication efforts could be staggering, with some drives reporting tens of thousands of rabbits destroyed, despite little effect on rabbit populations (Palmer 1897, Philip et al. 1955). Mechanical control methods were largely ineffective in controlling populations (Evans et al. 1970), and poisoning was more effective, although proper fencing of agricultural fields was also effective in preventing jackrabbit damage (Evans et al. 1982).

Following World War II and the advent of the nuclear age, the black-tailed jackrabbit was frequently used as a bioindicator for the uptake of radioactive elements, principally iodine $\left(\mathrm{I}^{131}, \mathrm{I}^{129}\right)$, cesium $\left(\mathrm{Cs}^{137}\right)$, and strontium $\left(\mathrm{Sr}^{89}, \mathrm{Sr}^{90}\right.$ ) (Hayden 1962, Turner et al. 1966, Rickard and Price 1984, Fitzner and Gray 1991). The assumption was that jackrabbits would provide a valid sample of radioisotope deposition across a given landscape due to their ubiquitous nature and the ease of collecting specimens (Turner et al. 1966). This research was undertaken at sites initially used to produce plutonium for World War II, as well as at nuclear technology and weaponry testing facilities. Much of this work was conducted on the Hanford Reserve in central Washington, the Idaho National Engineering Laboratory (INEL, previously the National Reactor Testing Site) in eastern Idaho, and the Nevada National Security Site (NNSS, formerly Nevada Test Site) in southern Nevada. At the NNSS, jackrabbits were used to monitor and investigate the uptake of radioactive elements following nuclear tests and to ensure that a minimal degree of risk existed for the transfer and bioaccumulation of radioactive materials to humans (Hayden 1962, Turner et al. 1966).

The black-tailed jackrabbit has also been used to measure the natural transport of radioactive materials around contaminated areas. Radioactive material transport was determined to be greater than initially hypothesized due 


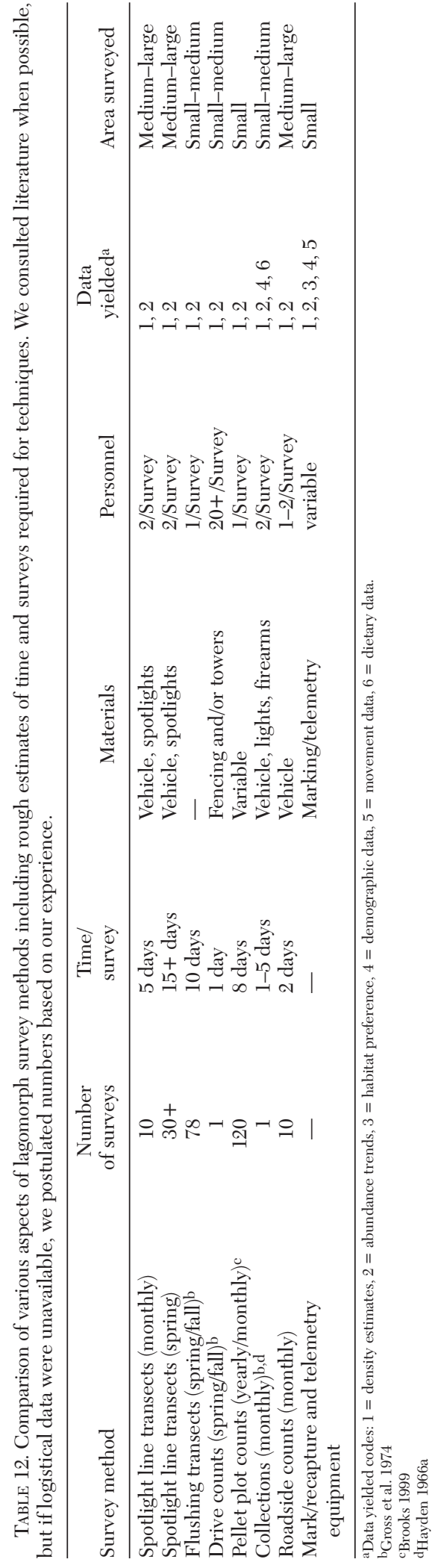

to the unexpectedly larger home-range size of jackrabbits at NNSS (Hayden 1962). The concept was more thoroughly investigated at the Hanford Reserve in Washington through a survey of fecal droppings wherein jackrabbits distributed radioactive materials up to $1.6 \mathrm{~km}$ from sources and some predators distributed material over $9 \mathrm{~km}$ from sources (O’Farrell and Gilbert 1975).

\section{Jackrabbit Survey Methods}

Many different methods, each with inherent strengths and weaknesses, have been employed to survey jackrabbits in the western United States. The following is a brief discussion of the more prevalent methods, their various advantages and disadvantages, logistics, and resultant data sets. We have found spotlight line transects to be the best method to monitor temporal and spatial variations in jackrabbit abundance over large areas in a cost- and time-efficient manner. However, our research needs did not require intensive demographic or ecological data on jackrabbits; other survey methods (Table 12) may be more effective in research programs requiring more specific data. Very few historical investigations have undertaken multiple comparable methods for monitoring jackrabbit populations, and as such, the opportunity to assess the accuracy of any one method in relation to another is generally unavailable.

\section{Spotlight Line Transects}

Spotlight line transects are a road-based survey method that uses multiple observers traveling along predetermined routes. Adequate sampling during surveys requires that transect lengths and time of day be adjusted in relation to the habitat type being surveyed, the density of rabbits, and the objective of the survey such that density estimates are robust and associated error is acceptable. Typically, the 2-observer method includes one observer driving a vehicle and recording all jackrabbits seen on the road, while the second observer records jackrabbits seen off road with a spotlight. Data recorded include location (UTM coordinates, odometer readings, etc.), perpendicular distance from the center of the road to the jackrabbit, observer, and time of night. Habitat information may also be recorded (Smith and Nydegger 1985). This 
version of the technique, developed by Smith and Nydegger (1985), is a preferred method to survey prey species of large raptors including Golden Eagles (Driscoll 2010).

In our experience, spotlight line transects should be at least $16-\mathrm{km}$ long to alleviate problems with uneven distribution of rabbits across a landscape. We also recommend that lights mounted on the vehicle be used to illuminate the immediate area surrounding the vehicle and handheld spotlights be used to search and scan the transect area.

A drawback of spotlight transects is that ambient moonlight can alert jackrabbits to the survey vehicle before they are observed (i.e., the surveys are more suitable to nights with less moonlight; Driscoll 2010). However, jackrabbits are more active on nights with more moonlight (Smith 1990). To balance these confounding issues, surveys should be conducted within a few days of a new or full moon to limit variability in detecting rabbits (Driscoll 2010). Other drawbacks of this method include the inability to survey in areas of dense vegetation cover where animal visibility declines with distance from the survey line (Wilde et al. 2012). This method is limited to roads and may present a biased view of the jackrabbit population. An example of such bias can be found in a study which noted that jackrabbits at the NNSS in the 1980s preferentially used habitats near human disturbances such as scrapings or roads (Hunter 1987). Other spotlight surveys, even those that do not follow the Smith and Nydegger (1985) protocol, have also been used for leporid investigations. A modification of the original method for spotlight surveys was successfully employed to obtain indices of jackrabbit population trends in central Idaho (Knick 1990). This survey incorporated only the vehicle's headlights to count jackrabbits crossing in front of the vehicle for 3 nights and used the highest count to obtain density estimates (Fagerstone et. al. 1980).

\section{Flushing Transects}

Flushing transects is a daylight method that involves walking a square-shaped $1.6-\mathrm{km}$ transect $(0.4 \mathrm{~km}$ on each side) and recording all jackrabbits seen or flushed. Observations of jackrabbits are recorded, along with their right-angle distance from the observer (Gross et al. 1974, Bartel et al. 2008). This method uses established transects that are meant to be repeated measurements of jackrabbit abundance over lengthy periods of time. Because these surveys are diurnal, the jackrabbit's nocturnal activity pattern may reduce detectability (Driscoll 2010). A modification of this method uses linear transects and observers on horseback, and it yields a 71\% higher estimate of black-tailed jackrabbit density than surveys on foot. These data suggest possible inaccuracies in density estimates derived from walking transects as a consequence of reduced jackrabbit visibility and hence detectability (Wywialowski and Stoddart 1988).

\section{Drive Counts}

The drive count is an attempt to count all jackrabbits in a particular area. Observers walk through the survey area at $10-$ to $20-\mathrm{m}$ intervals, and all jackrabbits that flush before them are counted, either by observers in towers, the drivers themselves, or observers at the end of the drive. Drives require many people, sometimes $>100$, to herd the rabbits toward a fence, net, corral, or other structure and have been used for centuries to harvest and control jackrabbits (Woodbury 1955, Palmer 1897). Theoretically the advantage of the drive count is that $100 \%$ census data can be obtained. The obvious disadvantage of this method is the large number of observers (at least 20) required for a single survey (Woodbury 1955). Another notable disadvantage is the large amount of preparation time and coordination that may be involved, particularly when observer towers or other structures are used (Gross et al. 1974). Similar issues apply in traditional drives toward a barrier in which many observers are stationed across a large geographic space.

\section{Pellet Plot Counts}

Jackrabbit studies have also used pellets and pellet plots as a census technique. Pellet surveys are also used to indicate lagomorph use of either natural environments (SosaBurgos 1991, Brooks 1999) or cultivated fields and rangelands (McAdoo et al. 1987). One survey method is to randomly select and clear small areas of $1 \mathrm{~m}^{2}$ or less and count all lagomorph pellets therein. Then, using a formula based on the number of pellets, the number of days since clearing, and a daily rate of defecation, a density estimate is obtained. These 
densities can then be extrapolated to calculate biomass for predator food-habit studies, as was done for bobcats (Lynx rufus) in Idaho (Knick 1990). Knick (1990) used the formula

$$
\mathrm{D}=[\mathrm{P} /(\mathrm{T} \times \mathrm{DR})] \times 10,000,
$$

where $\mathrm{D}=$ density, $\mathrm{P}=$ pellets $\cdot \mathrm{m}^{-2}, \mathrm{~T}=$ days since plot was cleared, and DR = defecation rate. The unit for the constant 10,000 is $\mathrm{m}^{2} \cdot \mathrm{ha}^{-1}$.

A disadvantage of this method is that rabbit densities must be high to get meaningful data, and it can be difficult to determine to what degree the persistence or movement via natural processes of jackrabbit pellets influences density estimates. It has been reported that estimated time for degradation of jackrabbit pellets could be up to 4.4 years (Flinders and Crawford 1977). Thus, it is possible to obtain grossly different density estimates using pellet surveys (between $2.4 \mathrm{ha}^{-1}$ and $8.4 \mathrm{ha}^{-1}$ ) than road surveys (between $0.0 \mathrm{ha}^{-1}$ and $0.4 \mathrm{ha}^{-1}$; Sosa-Burgos 1991). Habitats and various climatic conditions play a role in the persistence and detection of pellets. In southern Colorado, white-tailed jackrabbits occurred more frequently in meadow habitats than indicated by pellet surveys. This bias may have resulted from a more rapid dissolution of pellets in some habitats than in others (Bear and Hansen 1966).

\section{Collections}

Collecting jackrabbits by removal is a method used to determine distributions and to estimate numbers. Collections can also be used to gain insights into jackrabbit ecology and biology, including reproduction, disease, diet, and ecosystem contaminants (e.g., intake of radioactive elements). Firearms have been used as a collecting device, generally a .22 rifle or a shotgun. Systematic collecting, either by walking transects or shooting the animals from vehicles, can also provide density data if desired (Lechleitner 1958, Hayden 1962, French et al. 1965, Gross et al. 1974). Jackrabbit collections are a systematic method of determining sex ratios, reproductive condition, and diet (Hayden 1966a, Fagerstone et al. 1980). Reproductive investigations of the jackrabbit frequently use collections as a tool to estimate prepartum litter loss, litter size, and conception dates, as well as age structure within the population. Several methods of aging jackrabbits rely on the collection of animals including the epiphyseal closure method and the eye-lenses weight technique (Lechleitner 1959a, Tiemeier and Plenert 1964, Connolly et al. 1969). A major disadvantage of collecting jackrabbits is its destructive nature. However, it is the most effective tool for removing animals (Engeman et al. 2007), testing for disease (Philip et al. 1955), and determining radionucleotide uptake (Hayden 1962, Turner et al. 1966).

\section{Roadside Counts}

Roadside counts have long been used by biologists seeking estimates of relative abundance for jackrabbits. This method was used in Arizona as early as 1953 (Stair 1958) and in Nevada in the early 1960s (Hayden 1966b). More recently, through the 1980s and 1990s, roadside counts were employed in Harney County, Oregon (Ganskopp et al. 1993). By definition, roadside counts are subject to similar biases as spotlight line transects largely due to the reliance on roads. Roadside counts must be abundant and cover long stretches of road to provide valid results. Studies of the roadside count method in Arizona determined that there was so much variation between replicate counts on 30-mile surveys that accurate population estimates could not be obtained (Gallizioli 1953).

A variation on the roadside count is counting roadkills, which can also measure jackrabbit abundance (Adams and Adams 1959, Woffinden and Murphy 1989, Caro et al. 2000). Potential biases in the use of roadkill surveys include the high removal rates of roadkill by scavengers (which influence the detectability of roadkill to observers) and the length of time roadkills persist on roadways. Using roadside counts, observers in vehicles recorded only $6.5 \%$ of the roadkills in Tucson (Gerow et al. 2010) and approximately 5.8\% in Rio Grande Do Sul State, southern Brazil (Teixeira et al. 2013), compared to roadkills noted in surveys on foot. The observers also noted that smaller vertebrate roadkills were less noticeable to drivers and that larger species may go unobserved when deposited beyond the road surface/shoulder following an impact. Gerow et al. (2010) noted that carcasses of larger roadkills are often removed from road surfaces by scavengers, natural events, and passing motorists. 


\section{Mark-Recapture and Radiotelemetry}

Mark-recapture and radiotelemetry studies have been used in leporid monitoring and ecology since the mid-20th century (Lechleitner 1958, Donaho 1972, Stoddart 1970, Hungerford et al. 1974, Smith et al. 2002). In large part, these investigations center on the ecology and demographics of jackrabbits, but also examine mortality, home range, and movement of populations. The live-trapping of jackrabbits has been accomplished by nighttime spotlighting and netting (Griffith and Evans 1970); however, other capture techniques for live jackrabbit research include box traps and drive nets (Lechleitner 1958, Schaible 2007). Radiotelemetry has been used to investigate aspects of black-tailed jackrabbit biology, including activity patterns, homerange size, and mortality (Knowlton et al. 1968, Stoddart 1970, Smith 1990). Radio-collars have not been found to affect jackrabbit survival or health, though some changes in behavior including increased grooming were observed as a consequence of stiff collar materials (Wywialowski and Knowlton 1983). Among the advantages of this research method is the ability to gather large amounts of data on subjects such as demographics, movements, mortality agents, and habitat preferences. Mark-recapture and radiotelemetry investigations are time, capital, and personnel intensive to complete. However, recent advances in Global Positioning System (GPS) tracking technology can substantially reduce hardware and personnel costs while simultaneously increasing data-acquisition intervals, thus improving the cost effectiveness of this type of research. New GPS technologies provide an important tool for investigating the subjects previously addressed through radiotelemetry and in applying the resultant data to modern geographic information systems (GIS) technology. In this way, many new insights into jackrabbit ecology may be gained.

\section{Jackrabbit Habitat Models}

Geographic information systems (GIS) have been used to model jackrabbit habitat (Knick and Dyer 1997). This work primarily focused on the importance of jackrabbits as prey for breeding raptors such as Golden Eagles and Ferruginous Hawks (Buteo regalis). Knick and Dyer (1997) report that important variables for modeling jackrabbit habitat in
Idaho include the prevalence of shrubs, agriculture (maximum area of fields used in agriculture since 1979), and hydrographic features (number of cells in $1-\mathrm{km}$ radius with edges of wetlands, lakes, rivers, or streams), as well as spatial heterogeneity (a measure of the patchiness of the shrub mosaic).

Knick and Dyer (1997) also use and discuss the Mahalanobis distance statistic to rank $50-\mathrm{m}$ cells relative to mean habitat vector throughout their study area in Idaho. The Mahalanobis distance statistic is essentially a measure, in standard deviations, of the distance of any given point from a distribution mean. The Mahalanobis distance statistic is recommended with the caveat that landscapes should be well sampled to provide mean habitat vector, animals should be optimally distributed, and finally, distributions of the various habitat variables should not change (Knick and Rotenberry 1998). Verification surveys showed jackrabbit presence at close to the mean habitat vector.

\section{JaCKRabBits and BREEDing Raptors}

The black-tailed jackrabbit is a primary species in the diet of both the Golden Eagle and the Ferruginous Hawk in parts of western North America (Woodgerd 1952, Carnie 1954, Olendorff 1976, Bloom and Hawks 1982, Woffinden and Murphy 1989). The reproductive output for both species has been positively correlated with abundance in local jackrabbit populations (Woffinden and Murphy 1977, Smith et al. 1981, Steenhof et al. 1997). Jackrabbit abundance influences raptor breeding biology including sex ratios of chicks (Edwards et al. 1988), ratio of breeding pairs in the population, and nesting success (Woffinden and Murphy 1989). Jackrabbits are especially important to nesting Golden Eagles, composing up to $85 \%$ of the breeding season diet (Smith and Murphy 1979, Bloom and Hawks 1982) in some areas and influencing the timing of egg laying (Steenhof et al. 1997). The timing of breeding in Ferruginous Hawks is also closely associated with black-tailed jackrabbit biology and coincides with the jackrabbits' reproductive cycle. Ninety percent of jackrabbits present in Ferruginous Hawk nests in western Utah were under the age of 13 weeks (Woffinden and Murphy 1977). Ferruginous Hawks in South Dakota and eastern 
Colorado reportedly preyed on both whitetailed and black-tailed jackrabbits (Olendorff 1973, Lokemoen and Duebbert 1976).

\section{CONCLUSION}

Jackrabbit abundance in western North America has fluctuated over time and space and has varied widely across diverse landscapes. Historically, jackrabbit population fluctuations and dynamics have been important because of crop damage. More recently, however, the role of jackrabbits as prey has become an important consideration for biologists and natural resource managers. Some predators switch prey preferences as prey bases vary, resulting in use of alternative species not normally harvested in abundance (Esque et al. 2010). When predators target rare or protected species, populations of those species can be negatively impacted. These negative effects can be particularly evident if predator numbers are subsidized by abundant and easily acquired resources from the urban and suburban sources that have become common in western landscapes (Cypher and Scrivner 1992, Kristan and Boarman 2003, Gompper and Vanak 2008, Howe and Coates 2015). In Idaho, increased domestic lamb predation by coyotes was observed during years of reduced jackrabbit availability (Stoddart et al. 2001). This observation is only one of myriad reasons that monitoring jackrabbit populations and their possibly cyclic fluctuations, demographics, and ecological interactions is of continuing use to various parties.

The study and understanding of prey species (i.e., black-tailed and white-tailed jackrabbits) is crucial to comprehending trends associated with the habitat choices of protected raptor species, as well as our interactions with them. Golden Eagles in North America are the subject of much investigation as alternative energy development advances throughout much of their range (Kochert and Steenhof 2002). Many questions remain unanswered concerning jackrabbits. Quantitative measures of habitat preference are lacking for both white-tailed and black-tailed jackrabbits, as is knowledge of ecological interactions between sympatric white-tailed and black-tailed jackrabbits. Even the baseline ecology and population dynamics of whitetailed jackrabbits west of the Rocky Moun- tains are poorly documented. If the widespread reports of decline in white-tailed jackrabbit populations continue, understanding these issues will be crucial in conceptualizing and managing the species. Further research is required into the ecology and natural history of jackrabbits in the Mojave Desert. While many studies of desert jackrabbits are agenda driven (e.g., use of black-tailed jackrabbits as a testing agent for contaminants following nuclear testing), few have investigated the ecology of free-ranging jackrabbits in this ecosystem. Given the important role jackrabbit species play in the abundance of Golden Eagles and other predators, further study is needed regarding the dynamic forces at work within and upon jackrabbit populations.

\section{ACKNOWLEDGMENTS}

Funding and logistical support for this work was provided by the U.S. Geological Survey and the U.S. Fish and Wildlife Service. We thank Jessi L. Brown, University of Nevada, Reno, as well as 2 anonymous reviewers for improving our manuscript. The use of trade, product, or firm names in this publication is for descriptive purposes only and does not imply endorsement by the U.S. government.

\section{Literature Cited}

ADAms, H.B., AND L. ADAms. 1959. Black-tailed jackrabbit carcasses on the highways in Nevada, Idaho, and California. Ecology 40:718-720.

Amacher, A.J., R.H. Barrett, and S.L. Stephens. 2011. Observations of black-tailed jackrabbits (Lepus californicus) increase within forests treated with prescribed fire. Southwestern Naturalist 56: $115-118$.

Anderson, J.E., And M.L. Shumar. 1986. Impacts of black-tailed jackrabbits at peak population densities on sagebrush-steppe vegetation. Journal of Range Management 39:152-156.

Anderson, S., and A.S. Gaunt. 1962. A classification of the white-sided jack rabbits of Mexico. American Museum Novitates 2088:1-16.

Bartel, R.A., F.F. Knowlton, and L.C. Stoddart. 2008. Long-term patterns in mammalian abundance in northern portions of the Great Basin. Journal of Mammalogy 89:1170-1183.

Bates, J.W., AND M.O. Moretti. 1994. Golden Eagle (Aquila chrysaetos) population in eastern Utah. Great Basin Naturalist 54:248-255.

Bauer, K.L., M. Brooks, L.A. DeFalco, L. Derasary, K.K. Drake, N. Frakes, D. Gentilcore, R. Klinger, J.R. Matchett, R.A. McKinley, et AL. [COMpilERS]. 2011. Southern Nevada Complex Emergency Stabilization and Rehabilitation Final Report. U.S. Bureau of Land Management. 273 pp. 
Bear, G.D., And R.M. Hansen. 1966. Food habits, growth and reproduction of white-tailed jackrabbits in southern Colorado. Technical Bulletin 90, Agricultural Experiment Station, Colorado State University, Fort Collins, CO. 69 pp.

Bednarz, J.C., and J.A. CoOK. 1984. Distribution and numbers of the white-sided jackrabbit (Lepus callotis gaillardi) in New Mexico. Southwestern Naturalist 29:358-360.

Berger, J. 2008a. Undetected species losses, food webs, and ecological baselines: a cautionary tale from the Greater Yellowstone Ecosystem, USA. Oryx 42:139-142.

BERgER, J. 2008b Extant or extinct? White-tailed jackrabbits and Yellowstone's food web. Biological Sciences Faculty Publications, Paper 79.

Best, T.L. 1996. Lepus californicus. Mammalian Species 530:1-10.

Best, T.L., And T.H. Henry. 1993a. Lepus callotis. Mammalian Species 442:1-6.

Best, T.L., And T.H. Henry. 1993b. Lepus alleni. Mammalian Species 424:1-8.

Best, T.L., AND T.H. HenRY. 1994a. Lepus othus. Mammalian Species 458:1-5.

Best, T.L., And T.H. Henry. 1994b. Lepus arcticus. Mammalian Species 457:1-9.

BLACKBURN, D.F. 1973. Courtship behavior among whitetailed and black-tailed jackrabbits. Great Basin Naturalist 33:203-204.

BLoOM, P.H., and S.J. HawKs. 1982. Food habits of nesting Golden Eagles in northeast California and northwest Nevada. Journal of Raptor Research 16:110-115.

Bowen, R.E., K.J. MCMahon, AND R.W. MitcheLL. 1960. Infectious diseases in a black-tailed jackrabbit (Lepus californicus melanotis, Mearns) population in southwestern Kansas. Transactions of the Kansas Academy of Science (1903-) 63:276-284.

Braun, C.E., AND R.G. Streeter. 1968. Observations and occurrence of white-tailed jackrabbits in the alpine zone. Journal of Mammalogy 49:160-161.

Bronson, F.H. 1957. The ecology of the black-tailed jackrabbit (Lepus californicus melanotis, Mearns) in southwestern Kansas. Master’s thesis, Kansas State College of Agriculture and Applied Science. 89 pp.

Bronson, F.H., And O.W. TiemeiER. 1958a. Notes on crop damage by jackrabbits. Transactions of the Kansas Academy of Science (1903-) 61:226-229.

Bronson, F.H., AND O.W. Tiemeier. 1958b. Reproduction and age distribution of black-tailed jack rabbits in Kansas. Journal of Wildlife Management 22:409-414.

Bronson, F.H., AND O.W. TiEmeier. 1959. The relationship of precipitation and black-tailed jack rabbit populations in Kansas. Ecology 40:194-198.

Bвоокs, M. 1999. Effects of protective fencing on birds, lizards, and black-tailed hares in the western Mojave Desert. Environmental Management 23:387-400.

Brown, C.F., and P.R. Krausman. 2003. Habitat characteristics of 3 leporid species in southeastern Arizona. Journal of Wildlife Management 67:83-89.

Brown, D.E. 2012a. The case of the disappearing rabbits. SoLS (Arizona State University School of Life Sciences) 8:23-24.

Brown, D.E. 2012b. Bringing back the game: wildlife management in Arizona, 1912-1962. Arizona Game and Fish Department, Phoenix, AZ.

Brown, D.E., AND N.B. Carmony, EDITORs. 2009. Wildlife in Arizona Territory, 1865-1912. Arizona Game and Fish Department, Phoenix, AZ.
Brown, L. 1940. The distribution of the white-tailed jack rabbit (Lepus townsendii campanius Hollister) in Kansas. Transactions of the Kansas Academy of Science (1903-) 43:385-389.

Brown, L. 1947. Why has the white-tailed jackrabbit (Lepus townsendii campanius) become scarce in Kansas? Transactions of the Kansas Academy of Science (1903-) 49:455-456.

BuRNETT, W.L. 1926. Jack rabbits of eastern Colorado. Technical Report of Office of State Entomologist, Circular 52:1-18.

Carnie, S.K. 1954. Food habits of nesting Golden Eagles in the coast ranges of California. Condor 56:3-12.

Caro, M., J.A. Shargel, and C.J. Stoner. 2000. Frequency of medium-sized mammal road kills in an agricultural landscape in California. American Midland Naturalist 144:362-369.

CARTER, F.L. 1939. A study in jackrabbit shifts in range in western Kansas. Transactions of the Kansas Academy of Science (1903-) 42:431-435.

Cervantes, F.A. 1993. Lepus flavigularis. Mammalian Species 423:1-3.

Chapman, J.A., and G.R. Willner. 1978. Sylvilagus audubonii. Mammalian Species 106:1-4.

Chew, R.M., AND A.E. Chew. 1970. Energy relationships of the mammals of a desert shrub (Larrea tridentata) community. Ecological Monographs 40:1-21.

Clanton, C.W., and M.L. Johnson. 1954. White-tailed jack rabbit in Washington. Murrelet 35:15.

Clark, F.W. 1972. Influence of jackrabbit density on coyote population change. Journal of Wildlife Management 36:343-356.

Clark, W.R., and G.S. InNIS. 1982. Forage interactions and black-tailed jack rabbit population dynamics: a simulation model. Journal of Wildlife Management 46:1018-1035.

Clemons, C., L.G. Rickard, J.E. Kierans, and R.G. BotzLER. 2000. Evaluation of host preferences by helminths and ectoparasites among black-tailed jackrabbits in Northern California. Journal of Wildlife Diseases 36:555-558.

Collopy, M.W. 1983. A comparison of direct observations and collections of prey remains in determining the diet of Golden Eagles. Journal of Wildlife Management 47:360-368.

Connolly, G.E., M.L. Dudzinski, and W.M. Longhurst. 1969. The eye lens as an indicator of age in the black-tailed jackrabbit. Journal of Wildlife Management 33:159-164.

Costa W.R., K.A. Nagy, and V.H. Shoemaker. 1976. Observations of the behavior of jackrabbits (Lepus californicus) in the Mojave Desert. Journal of Mammalogy 57:399-402.

Couch, L.K. 1927. Migrations of the Washington blacktailed jackrabbit. Journal of Mammalogy 8:313-314.

Currie, P.O., AND D.L. Goodwin. 1966. Consumption of forage by black-tailed jackrabbits on salt-desert ranges of Utah. Journal of Wildlife Management 30:304-311.

Cypher, B.L., and J.H. Scrivner. 1992. Coyote control to protect endangered San Joaquin kit foxes at the Naval Petroleum Reserves, California. Pages 42-47 in Proc. 15th Vertebrate Pest Conference. University of California, Davis, CA.

Cypher, B.L., K.A. Spencer, And J.H. Scrivner. 1994. Food-item use by coyotes at the Naval Petroleum Reserves in California. Southwestern Naturalist 39: 91-95. 
Daniel, A., J. Holechek, R. Valdez, A. Tembo, L. SaIWANA, M. FusCO, AND M. CARDENAS. 1993. Jackrabbit densities on fair and good condition Chihuahuan Desert range. Journal of Range Management 46: $524-528$.

Davis, C.A., J.A. MeduIn, AND J.P. GRIFFING. 1975. Abundance of black-tailed jackrabbits, desert cottontail rabbits, and coyotes in southeastern New Mexico. Research Report 293, Agricultural Experiment Station, New Mexico State University, Las Cruces, NM.

DaWson, M.R. 1958. Later Tertiary Leporidae of North America. University of Kansas Paleontological Contributions, Vertebrata, Article 6.

DeFalco, L.A., T.C. Esque, S.J. Scoles-Sciulla, and J. RODGERS. 2010. Desert wildfire and severe drought diminish survivorship of the long-lived Joshua tree (Yucca brevifolia; Agavaceae). American Journal of Botany 97:243-250.

Desmond, M.J. 2004. Habitat associations and co-occurrence of Chihuahuan desert hares (Lepus californicus and L. callotis). American Midland Naturalist 151:414-419.

DE Vos, A. 1964. Range changes of mammals in the Great Lakes Region. American Midland Naturalist 71 210-231.

Dice, L.R. 1929. The phylogeny of Leporidae, with description of a new genus. Journal of Mammalogy $10: 340-344$

Dieter, C., AND D. Schaible. 2012. Reproduction and population characteristics of white-tailed jackrabbits in South Dakota. Great Plains Research 22:79-86.

Dieter, C.D., And D.J. Schaible. 2014. Distribution and population density of jackrabbits in South Dakota. Great Plains Research 24:127-134.

[DOE] TRW EnVIRONMENTAL SAFETy Systems, Inc. 1996. Lagomorph trends at Yucca Mountain, Nevada: 1990-1995. Prepared for Department of Energy. 11 pp.

Donoho, H.S. 1972. Dispersion and dispersal of whitetailed and black-tailed jackrabbits, Pawnee National Grasslands. In: US/IBP Grassland Biome Technical Report No. 96.55 pp

Driscoll, D.E. 2010. Protocol for Golden Eagle occupancy, reproduction, and prey population assessment. American Eagle Research Institute. 55 pp.

Driver, J.C., AND J.R. WOIDERSKI. 2008. Interpretation of the lagomorph index in the American Southwest. Quaternary International 185:3-11.

Eberhardt, L.E., and P. VAN Voris. 1986. Historical wildlife dynamics on the Dugway Proving Ground: population and disease trends in jack rabbits over two decades. Prepared for U.S. Army Test and Evaluation Command, Dugway Proving Ground. 56 pp.

Edwards, T.C., M.W. Collopy, K. Steenhof, and M.N. KocherT. 1988. Sex ratios of fledgling Golden Eagles. Auk 105:793-796.

Engeman, R.M., B. Constantin, and J. Bunting. 2007. The political, economic and management history of a successful exotic eradication: the case of black-tailed jackrabbits in one part of Florida. In: G.W. Witmer, W.C. Pitt, and K.A. Fagerstone, editors, Managing Vertebrate Invasive Species: Proceedings of an International Symposium. USDA/APHIS/ WS, National Wildlife Research Center, Fort Collins.

Esch, G.W., R.G. Beidleman, AND L.E. Long. 1959. Early breeding of black-tailed jackrabbit in southeastern Colorado. Journal of Mammalogy 40:442-443.
Esque, TC., K.E. Nussear, K.K. Drake, A.D. Walde, K.H. Berry, R.C. Averill-Murray, A.P. Woodman, W.I. Boarman, P.A. Medica, J. Mack, and J.S. Heaton. 2010. Effects of human population density, resource variability, and subsidized predators on desert tortoise populations in the Mojave Desert. Endangered Species Research 12:167-177. dx.doi.org/10.3354/ esr00298

Esque, T.C., C.R. Schwalbe, L.A. DeFalco, T.J. Hughes, AND R.B. DunCan. 2003. Effects of wildfire on small desert vertebrates, especially desert tortoises (Gopherus agassizii). Southwestern Naturalist 48:103-111.

Evans, J., and R.E. GRIFfith JR. 1972. Reproductive anomalies in black-tailed jackrabbits. Journal of Mammalogy 53:192-194.

Evans, J., P.L. Hegdal, and R.E. Griffith JR. 1970. Methods of controlling jackrabbits. Pages 109-116 in Proceedings of the 4th Vertebrate Pest Conference.

Evans, J., P. Hegdal, and R. Griffith. 1982. Wire fencing for controlling jackrabbit damage. Cooperative Extension Service, University of Idaho College of Agriculture, Bulletin 618. 7 pp.

Fagerstone, K.A., G.K. Lavoie, and R.E. Griffith Jr. 1980. Black-tailed jackrabbit diet and density on rangeland and near agricultural crops. Journal of Range Management 33:229-233.

Fatehi, M., R.D. Pieper, and R.F. Beck. 1988. Seasonal food habits of blacktailed jackrabbits (Lepus californicus) in southern New Mexico. Southwestern Naturalist 33:367-370

FaUtin, R.W. 1946. Biotic communities of the Northern Desert Shrub Biome in western Utah. Ecological Monographs 16:251-310.

Ferguson, H.L., and M. Atamian. 2012. Habitat connectivity for white-tailed jackrabbit (Lepus townsendii) in the Columbia Plateau ecoregion. Appendix A.4. in Washington Wildlife Habitat Connectivity Working Group (WHCWG), compilers, Washington Connected Landscapes Project: Analysis of the Columbia Plateau Ecoregion. Washington Department of Fish and Wildlife, and Washington Department of Transportation, Olympia, WA.

FisheR, J.L. 2012. Shifting prehistoric abundance of leporids at Five Finger Ridge, a central Utah archeological site. Western North American Naturalist 72: $60-68$

Fitzgerald, J.P., C.A. Meaney, and D.A. Armstrong. 1994. Mammals of Colorado. University Press of Colorado and Denver Museum of Natural History. $447 \mathrm{pp}$.

FITZNER, R.E., AND R.H. GRAY. 1991. The status, distribution and ecology of wildlife on the U.S. DOE Hanford Site: a historical overview of research activities ecological monitoring and assessment. Environmental Monitoring and Assessment 18:173-202.

Flinders, J.T., AND J.A. ChaPMAn. 2003. Black-tailed jackrabbit (Lepus californicus and allies). Pages 126-146 in G.A. Feldhammer, B.C. Thompson, and J.A. Chapman, editors, Wild mammals of North America: biology, management, and conservation. Johns Hopkins Press, Baltimore, MD.

Flinders, J.T., and J.A. CraWford. 1977. Composition and degradation of jackrabbit and cottontail fecal pellets, Texas High Plains. Journal of Range Management 30:217-220.

Flinders, J.T., and R.M. Hansen. 1971. Diets of jackrabbits within shortgrass ecosystem. IBP Grassland Biome Technical Report Number 98. 
Flinders, J.T., And R.M. Hansen. 1973. Abundance and dispersion of leporids within a shortgrass ecosystem. Journal of Mammalogy 54:287-291.

Flinders, J.T., AND R.M. Hansen. 1975. Spring population responses of cottontails and jackrabbits to cattle grazing shortgrass prairie. Journal of Range Management 28:290-293.

French, N.R., R. McBride, and J. Detmer. 1965. Fertility and population density of the black-tailed jackrabbit. Journal of Wildlife Management 29:14-26.

GaLLIZIOLI, S. 1953. Annual quail survey and investigations. Federal Aid Project W-53-R-3, Work Plan 3, Job 7. Completion Report.

Galloway, T. 2012. Ectoparasites of rabbits and hares in Manitoba, Canada, with observations on age-specific dispersal in Haemodipsus setoni (Phthiraptera: Anoplura: Polyplacidae). Canadian Entomologist 144:439-446.

Ganskopp, D., B. Myers, and S. Lambert. 1993. Blacktailed jackrabbit preferences for eight forages used for reclamation of Great Basin rangelands. Northwest Science 67:246-250.

Germano, D.J., R. Hungerford, and S.C. Martin. 1983 Responses of selected wildlife species to the removal of mesquite from desert grassland. Journal of Range Management 36:309-311.

Gerow, K., N.C. Kline, D.E. Swann, and M. Pokorny. 2010. Estimating vertebrate mortality on roads at Saguaro National Park, Arizona. Human-Wildlife Interactions 4:283-292.

GOMPPER, M.E., AND A.T. VANAK. 2008. Subsidized predators, landscapes of fear and disarticulated carnivore communities. Animal Conservation 11:13-14

Goodwin, D.L., And P.O. Currie. 1965. Growth and development of black-tailed jackrabbits. Journal of Mammalogy 46:96-98.

Grayson, D.K. 1977. On the Holocene history of some Great Basin lagomorphs. Journal of Mammalogy 58: $507-513$.

Grayson, D.K. 1987. The biogeographic history of small mammals in the Great Basin: observations on the last 20,000 years. Journal of Mammalogy 68:359-375.

GRIFFITH, R.E., AND J. Evans. 1970. Capturing jackrabbits by night lighting. Journal of Wildlife Management 34:637-639.

Gross, J.E., L.C. Stoddart, and F.H. Wagner. 1974. Demographic analysis of a northern Utah jackrabbit population. Wildlife Monographs 40:3-68.

Gruell, G.E. 1996. Historical and modern roles of fire in pinyon-juniper. 1999. Pages 24-28 in S.B. Monson and R. Stevens, compilers, Proceedings-ecology and management of pinyon-juniper communities within the Interior West: 1997 September 15-18: Provo, Utah. Proc. RMRS-P-9, USDA Forest Service, Rocky Mountain Research Station, Ogden, UT.

Gunther, K.A., R.A. Renkin, J.C. Halfpenny, S.M. Gunther, T. Davis, P. Schullery, and L. WhitTlesey 2009. Presence and distribution of white-tailed jackrabbit in Yellowstone National Park. Yellowstone Science 17:24-32.

Halanych, K.M., J.R. Demboski, B.J. Van Vuuren, D.R. KLEIN, AND J.A. COOK. 1999. Cytochrome $b$ phylogeny of North American hares and jackrabbits (Lepus, Lagomorpha) and the effects of saturation in outgroup taxa. Molecular Phylogenetics and Evolution $11: 213-221$
Hansen, R.M., and G.D. Bear. 1963. Winter coats of white-tailed jackrabbits in southwestern Colorado. Journal of Mammalogy 44:420-422.

Haskell, H.S., and H.G. Reynolds. 1947. Growth, developmental food requirements, and breeding activity of the California jack rabbit. Journal of Mammalogy 28:129-136.

Hayden, P. 1962. The ecology and radio-assay of blacktailed jack rabbits on Jackass Flat, Nye Co., Nevada. Master's thesis, University of California, Los Angeles, CA. 196 pp.

Hayden, P. 1966a. Food habits of black-tailed jackrabbits in southern Nevada. Journal of Mammalogy 47: $42-46$.

Hayden, P. 1966b. Seasonal occurrence of jackrabbits on Jackass Flat, Nevada. Journal of Wildlife Management 30:835-838.

Heaton, T.H. 1985. Quaternary paleontology and paleoecology of Crystal Ball Cave, Millard County, Utah: with emphasis on mammals and description of a new species of fossil skunk. Great Basin Naturalist 45:337-390.

Henke, S.E., D.B. Pence, S. Demarais, and J.R. Johnson. 1990. Serologic survey of selected zoonotic disease agents in black-tailed jack rabbits from western Texas. Journal of Wildlife Diseases 26:107-111.

Hoeman, J.V. 1964. High altitude records for white-tailed jackrabbits. Journal of Mammalogy 45:495.

Howe, K.B., AND P.S. COATES. 2015. Observations of territorial breeding common ravens caching eggs of Greater Sage-Grouse. Journal of Fish and Wildlife Management 6:187-190.

Hungerford, C.R., C.H. Lowe, and R.L. Madsen. 1974. Population studies of the desert cottontail (Sylvilagus audubonii), black-tailed jackrabbit (Lepus californicus) and Allen's jackrabbit (Lepus alleni) in the Sonoran Desert. US/IBP Desert Biome Research Memorandum 74-23. 22 pp.

Hunter, R.B. 1987. Jackrabbit shrub interactions in the Mojave Desert. Pages 88-92 in F.D. Provensa, J.T. Flinders, and E.D. MacArthur, editors, Proceedings_-symposium on plant-herbivore interactions. USDA Forest Service, Ogden, UT.

James, T.R., and R.W. Seabloom. 1969. Reproductive biology of the white-tailed jack rabbit in North Dakota. Journal of Wildlife Management 33:558-568.

Jardine, C., G.A. Wobeser, and E. Simko. 2004. Malignant tumors in two white-tailed jackrabbits (Lepus townsendii). Journal of Wildlife Diseases 40:754-758.

Johnson, D.R., And J.M. Peek. 1984. The black-tailed jackrabbit in Idaho: life history, population dynamics and control. Bulletin 637, Cooperative Extension Service, University of Idaho College of Agriculture. $16 \mathrm{pp}$.

Johnson, R.D., AND J.E. ANDERson. 1984. Diets of blacktailed jack rabbits in relation to population density and vegetation. Journal of Range Management 37:79-83.

JoRGENSEN, C.D. 1962. Disturbance of mammal traps by jack rabbits. Great Basin Naturalist 22:83-86.

Kamler, J.F., and W.B. Ballard. 2006. Ear flashing behavior of black-tailed jackrabbits (Lepus californicus). American Midland Naturalist 155:402-403.

Keane, R.E., J.K. Agee, P. Fule, J.E. Keeley, C. Key, S.G. Kitchen, R. Miller, and L.A. Schulte. 2008. Ecological effects of large fires on U.S. landscapes: benefit or catastrophe? International Journal of Wildland Fire 17:696-712. 
KNICK, S.T. 1990. Ecology of bobcats relative to exploitation and a prey decline in southeastern Idaho. Wildlife Monographs 108:3-42.

KNICK, S.T., AND D.L. Dyer. 1997. Distribution of blacktailed jackrabbit habitat determined by GIS in southwestern Idaho. Journal of Wildlife Management 61:75-85.

KNick, S.T., and J.T. Rotenberry. 1998. Limitations to mapping habitat use areas in changing landscapes using the Mahalanobis distance statistic. Journal of Agricultural, Biological, and Environmental Statistics 3(3):311-322.

Knowlton, F.F., P.E. Martin, and J.C. Haug. 1968. A telemetric method for determining animal activity. Journal of Wildlife Management 32:943-948.

Kochert, M.N., And K. Steenhof. 2002. Golden Eagles in the U.S. and Canada: status, trends, and conservation challenges. Journal of Raptor Research 36: $32-40$.

Kochert, M.N., K. Steenhof, L.B. Carpenter, and J.M. Marzluff. 1999. Effects of fire on Golden Eagle territory occupancy and reproductive success. Journal of Wildlife Management 63:773-780.

Krebs, C.J. 1996. Population cycles revisited. Journal of Mammalogy 77:8-24.

Kristan, W.B., III, and W.I. Boarman. 2003. Spatial distribution of risk of desert tortoise (Gopherus agassizii) predation by common ravens (Corvus corax). Ecology 84:2432-2443.

LECHLEITNER R.R. 1958. Movements, density and mortality in a black-tailed jackrabbit population. Journal of Wildlife Management 22:371-384.

LeChleitner R.R. 1959a. Sex ratio, age classes and reproduction of the black-tailed jack rabbit. Journal of Mammalogy 40:63-81.

LECHLEITNER R.R. 1959b. Some parasites and infectious diseases in a black-tailed jackrabbit population in the Sacramento Valley, California. California Fish and Game 45(2):84-91.

LEOPOLD, A. 1947. The distribution of Wisconsin hares. Wisconsin Academy of Sciences, Arts and Letters 37:1-14.

LEWIS, J.H. 1946. Planting practice to reduce crop damage by jackrabbits. Journal of Wildlife Management 10:277.

LightFoot, D.C., A.D. Davidson, C.M. McGlone, and D.G. PARKer. 2010. Rabbit abundance relative to rainfall and plant production in northern Chihuahuan Desert grassland and shrubland habitats. Western North American Naturalist 70:490-499.

Lim, B.K. 1987. Lepus townsendii. Mammalian Species 288:1-6.

Link, S.O., C.W. Keeler, R.W. Hill, and E. Hagen. 2006. Bromus tectorum cover mapping and fire risk. International Journal of Wildland Fire 15:113-119.

Lipson, M.P., and P.R. Kraussman. 1988. Parasites of desert leporids in the Picacho Mountains, Arizona. Southwestern Naturalist 33:487-488.

Lokemoen, J.T., And H.F. Duebbert. 1976. Ferruginous hawk nesting ecology and raptor populations in northern South Dakota. Condor 78:464-470.

LONGLAND, W.S. 1991. Risk of predation and food consumption by black-tailed jackrabbits. Journal of Range Management 44:447-450.

Lorenzo, C., D.E. Brown, S. Amirsultan, and M. Garcia. 2014. Evolutionary history of the antelope jackrabbit, Lepus alleni. Arizona-Nevada Academy of Sciences 45:70-75.
Marín, A.I., L. Hernandez, and J.W. Laundre. 2003. Predation risk and food quantity in the selection of habitat by black-tailed jackrabbit (Lepus californicus): an optimal foraging approach. Journal of Arid Environments 55:101-110.

Marzluff, J.M., S.T. Knick, M.S. VeKasy, L.S. Schueck, and T.J. ZarRieLlo. 1997. Spatial use and habitat selection of Golden Eagles in southwestern Idaho. Auk 114:673-687.

McAdoo, J.K., W.S. Longland, G.J. Cluff, and D.A. KLEBENOW. 1987. Use of new rangeland seedings by black-tailed jackrabbits. Journal of Range Management 40:520-524.

McAdoo, J.K., L.T. Vermeire, and W. Gilgert. 2004. The other grazers. Rangelands 26:30-37.

McAdoo, J.K., AND J.A. Young. 1980. Jackrabbits. Rangelands 2:135-138.

Miller, R.F., J.D. Bates, T.J. Svejcar, F.B. Pierson, and L.E. Eddleman. 2005. Biology, ecology and management of western juniper. Technical Bulletin 152 , Agricultural Experiment Station, OSU. 82 pp.

Mohr, W.P., AND C.O. Mohr. 1936. Recent jack rabbit populations at Rapidan, Minnesota. Journal of Mammalogy 17:112-114.

Murray, D.L. 2003. Snowshoe and other hares. Pages 147-175 in G.A. Feldhammer, B.C. Thompson, and J.A. Chapman, editors, Wild Mammals of North America: biology, management, and conservation. Johns Hopkins Press, Baltimore, MD.

Nelson, E.W. 1909. The rabbits of North America. North American Fauna 29, U.S. Biological Survey, Washington, DC. 314 pp.

Nydegger, N.C., And G.W. Smith. 1984. Prey populations in relation to Artemisia vegetation types in southwestern Idaho. Pages 152-156 in Proceedingssymposium on the biology of Artemisia and Chrysothamnus. 9-13 July 1984, Provo, UT.

O'Farrell, T.P., and R.O. Gilbert. 1975. Transport of radioactive materials by jackrabbits on the Hanford Reservation. Health Physics 29:9-15.

OLENDORFF, R.R. 1973. The ecology of nesting birds of prey of northeastern Colorado. US/IBP Grassland Biome Technical Report No. 211. 237 pp.

OlEndoRFF, R.R. 1976. The food habits of North American Golden Eagle. American Midland Naturalist 95: 231-236.

Oregon Department of Fish and Wildlife. 2015. How to rabbit hunt. http://www.dfw.state.or.us/ resources/hunting/docs/Howtohuntrabbit.pdf

Palmer, T.S. 1897. The jackrabbits of the United States. Bulletin No. 8, USDA Division of Biological Survey. $106 \mathrm{pp}$.

Philip, C.B., J.F. Bell, AND C.L. LaRson. 1955. Evidence of infectious diseases and parasites in a peak population of black-tailed jack rabbits in Nevada. Journal of Wildlife Management 19:225-233.

Rickard, W.H., and K.R. PRICE. 1984. Iodine in terrestrial wildlife on the U.S. Department of Energy's Hanford site in south central Washington. Environmental Monitoring and Assessment 4:379-388.

Rogowitz, G.L. 1992. Reproduction of white-tailed jackrabbits on semi-arid range. Journal of Wildlife Management 56:676-684.

Rogowitz, G.L., AND M.L. Wolfe. 1991. Intraspecific variation in life-history traits of the white-tailed jackrabbit (Lepus townsendii). Journal of Mammalogy 72:796-806. 
Rosasco, M.E. 1957. Seasonal abundance of the tick Dermocentor parumapertus on the black-tailed jackrabbit, with notes on other ectoparsites. Journal of Mammalogy 38:485-490.

Roundy, B.A., G.J. Cluff, J.K. McAdoo, and R.A. Evans. 1985. Effects of jackrabbit grazing, clipping, and drought on crested wheatgrass seedlings. Journal of Range Management 38:551-555.

Rusch, D.H. 1965. Some movements of black-tailed jackrabbits in northern Utah. Master's thesis, Utah State University, Logan, UT. 43 pp.

SALO, L.F. 2004. Population dynamics of red brome (Bromus madritensis subsp. rubens): times for concern, opportunities for management. Journal of Arid Environments 57:291-296.

SCHAible, D.J. 2007. Status, distribution, and density of white-tailed and black-tailed jackrabbits in South Dakota. Master's thesis, South Dakota State University, Brookings, SD. 144 pp.

Schaible, D., And C. Dieter. 2011. Health and fertility implications related to seasonal changes in kidney fat index of white-tailed jackrabbits in South Dakota. Great Plains Research 21:89-94.

Schaible, D.J., C.D. Dieter, R.D. Nieger, and M.B HILDRETH. 2011. Calodium hepaticum in white-tailed jackrabbits in South Dakota. Prairie Naturalist 43: $56-58$.

SchmitT, D.N. 1995. The taphonomy of Golden Eagle prey accumulations at Great Basin roosts. Journal of Ethnobiology 15:237-256.

Schmitt, D.N., D.B. MadSEN, AND K. Lupo. 2002. Smallmammal data on Early and Middle Holocene climates in the Bonneville Basin, USA. Quaternary Research $58: 255-260$.

Shaffer, B.S., AND K.M. Gardner. 1995. The rabbit drive through time: analysis of the North American ethnographic and prehistoric evidence. Utah Archeology $8: 13-2.5$.

Shryock, D.F., T.C. Esque, And F.C. Chen. 2015. Topography and climate are more important drivers of long-term, post-fire vegetation recovery than timesince-fire in the Sonoran Desert, USA. Journal of Vegetation Science, dx.doi.org/10.1111/jvs.12324

Shultz, L.M., AND L.G. RicKard. 1985. Helminth parasites of the white-tailed jackrabbit, Lepus townsendii, from northwestern Colorado and southern Wyoming. Great Basin Naturalist 40:604-606.

Smith, D.G., AND J.R. Murphy. 1979. Breeding response of raptors to jackrabbit density in the Eastern Great Basin Desert of Utah. Journal of Raptor Research 13:1-14.

Smith, D.G., J.R. Murphy, and N.D. Woffinden. 1981. Relationships between jackrabbit abundance and ferruginous hawk reproduction. Condor 83:52-56.

SмiтH, G.W. 1990. Home range and activity patterns of black-tailed jackrabbits. Great Basin Naturalist 50: 249-256.

Smith, G.W., and N.C. Nydegger. 1985. A spotlight, line-transect method for surveying jack rabbits. Journal of Wildlife Management 49:699-702.

Smith, G.W., L.C. Stoddart, and F.F. Knowlton. 2002. Long-distance movements of black-tailed jackrabbits. Journal of Wildlife Management 66:463-469.

Sosa Burgos, L.M. 1991. Ecology of two coexisting populations of lagomorphs in the Mojave Desert, Lepus californicus and Sylvilagus audubonii. Doc- toral thesis, University of California, Los Angeles, CA. 118 pp.

Sparks, D.R. 1968. Diet of black-tailed jackrabbits on sandhill rangeland in Colorado. Journal of Range Management 21:203-208.

STAIR, J.L. 1958. Cottontail hunt information and surveys. Federal Aid Project W-53-R-8, Work Plan 2\&3, Job 13. Completion Report.

Steenhof, K., AND M. Kochert. 1988. Dietary responses of three raptor species to changing prey densities in a natural environment. Journal of Animal Ecology $57: 37-48$.

Steenhof, K., M.N. Kochert, and T.L. McDonald. 1997. Interactive effects of prey and weather on Golden Eagle reproduction. Journal of Animal Ecology 66: 350-362.

STODDART, L.C. 1970. A telemetric method for detecting jackrabbit mortality. Journal of Wildlife Management 34:501-507.

STODDART, L.C. 1984. Site fidelity and grouping of neonatal jack rabbits, Lepus californicus. Journal of Mammalogy 65:136-137.

STODDART L.C. 1985. Severe weather related mortality of black-tailed jackrabbits. Journal of Wildlife Management 49:696-698.

Stoddart, L.C., R.E. Griffiths, and F.F. Knowlton. 2001. Coyote responses to changing jackrabbit abundance affect sheep. Journal of Range Management 54:15-20.

Svilha, A., AND R.D. SvilHa. 1940. Annotated list of the mammals of Whitman County, Washington. Murrelet 3:35-58.

TAPIA, I. 2010. Genetic diversity and connectivity of white-tailed jackrabbit populations in Iowa with notes on seasonal home ranges. Master's thesis, Iowa State University, Ames, IA. 94 pp.

Teixeira, F.Z., A.V.P. Coelho, I.B. Esperandio, and A. KINDEL. 2013. Vertebrate road mortality estimates: effects of sampling methods and carcass removal. Biological Conservation 157:317-323.

Thomas, H.H., and T.L. Best. 1994. Lepus insularis. Mammalian Species 465:1-3.

Tiemeier, O.W., And M.L. Plenert. 1964. A comparison of three methods for determining the age of black-tailed jackrabbits. Journal of Mammalogy 45: 409-416.

Traphagen, M.B. 2011. Final report on the status of the white-sided jackrabbit (Lepus callotis gaillardi) in New Mexico. Final Report, New Mexico Department of Game and Fish, Santa Fe, NM. 22 pp.

Turner, F.B., R.H. Rowland, and R.A. Wood. 1966. Nuclear engineering and wildlife: radioactivity in jackrabbits after the Sedan test. Journal of Wildlife Management 30:433-443.

Van Auken, O.W. 2000. Shrub invasions of North American semiarid grasslands. Annual Review of Ecology and Systematics 31:197-215.

Vorhies, C.T., AND W.P. TAYLOR. 1933. The life histories and ecology of jack rabbits, Lepus alleni and Lepus californicus ssp., in relation to grazing in Arizona. Technical Bulletin 49, Agriculture Experiment Station, University of Arizona. Pages 471-587.

Wagner, F.H., AND L.C. Stoddart. 1972. Influence of coyote predation on black-tailed jackrabbit populations in Utah. Journal of Wildlife Management 36: 329-342. 
Washington Department of Fish and WiLdLife. 2014. Washington State Migratory Waterfowl and Upland Game Seasons. [Accessed 2 August 2015]. http://wdfw .wa.gov/publications/01635/wdfw01635.pdf

WatKIns, L.C., AND R.M. NowaK. 1973. The white-tailed jackrabbit in Missouri. Southwestern Naturalist 18: 352-354.

WedDELL, B.J. 2001. Fire in steppe vegetation of the northern Intermountain ecoregion. Idaho Bureau of Land Management Technical Bulletin 01-14. 28 pp.

West, R.R., M.H. Bartel, and M.L. Plenert. 1961. Use of forms by the black-tailed jackrabbit in southwestern Kansas. Transactions of the Kansas Academy of Science (1903-) 64:344-348.

White, J.A. 1991. North American Leporinae (Mammalia: Lagomorpha) from Late Miocene (Clarendonian) to Latest Pliocene (Blancan). Journal of Vertebrate Paleontology 11:67-89.

Wilde, J.T., C.T. Lindsay, And J.J. Nugent. 2012. Blacktailed jackrabbit monitoring report for fiscal year 2012. HNF-54234, prepared for USDOE. 18 pp.

Woffinden, N.D., AND J.R. Murphy. 1977. Population dynamics of the Ferruginous Hawk during a prey decline. Great Basin Naturalist 37:411-425.

Woffinden, N.D., AND J.R. Murphy. 1989. Decline of a Ferruginous Hawk population: a 20-year summary. Journal of Wildlife Management 53:1127-1132.
Woodbury, A.M. 1955. Ecology of the Great Salt Lake Desert: I. An annual cycle of the desert jackrabbit. Ecology 36:353-356.

Woodgerd, W. 1952. Food habits of the Golden Eagle. Journal of Wildlife Management 16:457-459.

Wooster, L.D. 1935. Notes on the effects of drought on animal population in western Kansas. Transactions of the Kansas Academy of Science (1903-) 38:351-353.

WRight, H.A., L.F. NEUENSCHWANDER, AND C.M. BRITTON. 1979. The role and use of fire in sagebrush-grass and pinyon-juniper plant communities: a state of the art review. General Technical Report INT-58, USDA Forest Service, Intermountain Forest and Range Experiment Station, Ogden, UT. 48 pp.

WywialowsKi, A.P., and F.F. KNOWLTON. 1983. Effect of simulated radio-transmitters on captive black-tailed jackrabbits. In: D.G. Pincock, editor, Proceedings4th International Conference on Wildlife Biotelemetry, 22-24 August 1983.

WYWIALOWSKI, A.P., AND L.C. STODDART. 1988. Estimation of jack rabbit density: methodology makes a difference. Journal of Wildlife Management 52:57-59.

Received 13 January 2015 Accepted 30 September 2015 